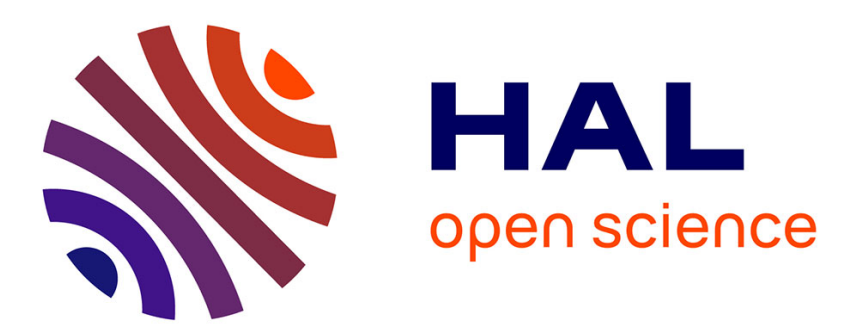

\title{
Nubian technology in northern Arabia: Impact on interregional variability of Middle Paleolithic industries
}

Yamandu Hilbert, Rémy Crassard, Guillaume Charloux, Romolo Loreto

\section{To cite this version:}

Yamandu Hilbert, Rémy Crassard, Guillaume Charloux, Romolo Loreto. Nubian technology in northern Arabia: Impact on interregional variability of Middle Paleolithic industries. Quaternary International, 2017, 435, pp.77-93. 10.1016/j.quaint.2015.11.047 . hal-01829347

\section{HAL Id: hal-01829347 \\ https://hal.science/hal-01829347}

Submitted on 4 Jul 2018

HAL is a multi-disciplinary open access archive for the deposit and dissemination of scientific research documents, whether they are published or not. The documents may come from teaching and research institutions in France or abroad, or from public or private research centers.
L'archive ouverte pluridisciplinaire HAL, est destinée au dépôt et à la diffusion de documents scientifiques de niveau recherche, publiés ou non, émanant des établissements d'enseignement et de recherche français ou étrangers, des laboratoires publics ou privés. 


\title{
Nubian technology in northern Arabia: Impact on interregional variability of Middle Paleolithic industries
}

\author{
Yamandú H. Hilbert a , Rémy Crassard ${ }^{\mathrm{a}, ~}{ }^{*}$, Guillaume Charloux ${ }^{\mathrm{b}}$, Romolo Loreto $^{\mathrm{c}}$ \\ a CNRS, UMR 5133 'Archéorient', Maison de l'Orient et de la Méditerranée, 7 rue Raulin, 69007 Lyon, France \\ b CNRS, UMR 8167 'Orient \& Méditerranée', 27 rue Paul Bert, 94204 Ivry-sur-Seine Cedex, France \\ ' Università degli Studi di Napoli 'L'Orientale', Dipartimento Asia, Africa e Mediterraneo, Piazza San Domenico Maggiore, 12, 80134 Naples, Italy
}

\section{A R T I C L E I N F O}

\section{Article history:}

Available online 20 December 2015

\section{Keywords:}

Middle Paleolithic

Lithic industries

Nubian Complex

Levallois technology

Saudi Arabia

\begin{abstract}
A B S T R A C T
Since 2013, the authors have conducted archaeological surveys across the Al-Jawf province in northern Saudi Arabia. In the past two seasons, 48 sites were mapped and characterized by the presence of Levallois technology and, therefore, attributed to the Middle Paleolithic of Arabia. Preferential Levallois reduction using different methods of dorsal core preparation have been found at these sites. The technological variability includes Nubian Levallois methods, preferential Levallois with centripetal preparation, as well as recurrent centripetal reduction methods. In Arabia, sites with Nubian Levallois reduction are known from southern Oman, eastern Yemen, and central Saudi Arabia, while in Africa this reduction method has been identified across much of the northeastern continent. Preferential Levallois with centripetal preparation and recurrent centripetal Levallois methods have been found across Saudi Arabia, Yemen, Oman, and the United Arab Emirates. Outside of Arabia, these methods have been found in many regions across the Old World. In this paper, we present the results from technological analyses on the Middle Paleolithic assemblages from the newly discovered Al-Jawf sites. The technological data are used to place these sites into a wider regional framework, assessing whether connections with known lithic industries from across the Near East and northeastern Africa can be surmised.
\end{abstract}

(C) 2015 Elsevier Ltd and INQUA. All rights reserved.

\section{Introduction}

The study of complex events that unfolded as Anatomically Modern Humans (AMH) groups spread out of Africa has long been one of the utmost aspirations of Paleolithic archeology (Cameron and Groves, 2004; Klein, 2009). This endeavor, however, is hampered by the fragmentary character of the archaeological record and the lack of research in many of the most pertinent regions related to this question. This is particularly true for the early stages of the AMH expansion, approximately 100-40 ka. Until now, two distinct routes out of Africa had been postulated: a) through the Levantine Corridor (e.g. Bar-Yosef, 1987; Derricourt, 2005) and, b) across the Red Sea via the Southern Dispersal Route (e.g. Lahr and Foley, 1994; Quintana-Murci et al., 1999; Macaulay et al., 2005; Armitage et al., 2011; Ghirotto et al., 2011), both irrevocably leading across, or close to, the Arabian Peninsula. The ability to track routes of expansion, however, is highly dependent upon hominid fossil

\footnotetext{
* Corresponding author.

E-mail address: remy.crassard@mom.fr (R. Crassard).
}

remains, which are absent in the Pleistocene archaeological record of Arabia, in addition to long and well-dated Paleolithic sequences, which are extremely rare across the Peninsula.

The importance of the Arabian Peninsula as one of the steppingstones for modern human expansions out of Africa and as the possible southernmost range of the Neanderthal occupation in the Near East is becoming increasingly obvious, as more publications on these subjects become available (e.g. Petraglia and Rose, 2009; Armitage et al., 2011; Petraglia, 2011; Rose et al., 2011; Delagnes et al., 2012, 2013; Petraglia et al., 2012; Crassard et al., 2013). Furthermore, some of the lithic assemblages found across the Arabian Peninsula hint at the existence of regionally specific developmental trajectories (Marks, 2009). These aspects make the study of the Arabian Prehistory exceedingly fascinating and crucial for reconstructing prehistory on a wider scale. In the absence of hominid fossil remains, however, prehistorians have relied on lithic evidence, in order to track population expansions. Far from claiming that lithics equate to biological species, we uphold the notion that they do represent the cultural activities of populations within a given geographic and chronological frame (e.g. Richter et al., 2012; Marks and Rose, 2014). The presence of Nubian Complex sites in 
Arabia, therefore, is one of the scarce snippets of evidence for an African lithic industry found outside of the continent (Rose et al., 2011; Crassard and Hilbert, 2013; Usik et al., 2013).

The Afro-Arabian Nubian Complex (Rose et al., 2011) is a Middle Stone Age (in Africa) and Middle Paleolithic (in Arabia) technocomplex primarily distinguished by the use of the Nubian Levallois method, which is a highly specific approach to point manufacture. Nubian core technology is a regional variant of the preferential Levallois method of point production (e.g. Guichard and Guichard, 1965, 1968; Bordes, 1980; Van Peer, 1992; Crassard and Thiébaut, 2011; Crassard and Hilbert, 2013; Usik et al., 2013). Cores are characterized by their prepared preferential striking platforms, triangular/sub-triangular shapes, and a specific opposed platform preparation of the core working surface (Crassard and Hilbert, 2013; Usik et al., 2013). While classic centripetal and recurrent Levallois production methods are generally spread across Africa and Eurasia throughout the MSA/Middle Paleolithic, presenting a wide chronological range, as well as being species transgressive, the Nubian Levallois reduction method has, thus far, presented a relatively concise temporal and geographic range. Sites are known from North and East Africa, as well as South and Central Arabia, while absolute ages are rare, sites displaying Nubian technology fall chronologically between 120 and 55 ka BP (reviews on the Nubian Complex are given in Rose et al., 2011 and Crassard and Hilbert, 2013).

Further advancing this debate and touching upon the roll of the Afro-Arabian Nubian Complex in an interregional context, Rose and Marks (2014) have proposed that the Early Upper Paleolithic (EUP) in the Levant may have arisen, in part, from technological influences found in the Arabian Nubian Complex. The authors hypothesize that the EUP in the Levant arose from technological developments that originated in Arabian and the Levant, which is to say that a fusion of technological elements identified in these areas is the basis from which the Emirian culture, the root of the EUP, sprung. The technological elements highlighted by the authors encompass the bidirectional preparation of cores, the development of crest preparation and the shift from a preferential production system to a serial bidirectional production of elongated points and blades. Rose and Marks (2014) highlight southern Jordan and northwestern Arabia as possible areas where such a fusion may be detected. Here we present results of our survey and analysis from the Al-Jawf sites located in northern Saudi Arabia. The sites and data presented here will add to the growing Arabian Paleolithic record and help evaluate: a) cultural connections with surrounding areas, namely northeastern Africa and the Near East; b) Rose and Marks's (2014) Middle Paleolithic to Upper Paleolithic transition and fusion hypotheses; and finally c) the northernmost distribution of the Nubian technology within the Arabian Peninsula.

\section{Geographical and geological setting}

The Al-Jawf province is located in the north of Saudi Arabia. The archaeological investigations were concentrated around the city of Dumat al-Jandal, about $200 \mathrm{~km}$ south of the Jordanian border, and located in the north-central part of the province. The landscape is marked by a turbulent topography with many grabens, faults, and folds. This is in part a result of the rifting activities of the Arabian Shelf and the area's orientation relative to the Hail arch's axis (northern section of the Central Arabian Graben System). The Wadi as-Sirhan fault, which trends west-northwest, is the most defining of the countless faults and graben systems in the region (Fig. 1). Except for the plateaus and escarpments created by the tectonic and erosional activities in the area, eolian sediments cover a great part of the Al-Jawf province. To the south of Dumat al-Jandal, the barkhanoid ridge-type dunes of the Nefud Desert tower up to
$200 \mathrm{~m}$ in height. The majority of these dunes are stabilized as the Nefud contains more perennial vegetation than the surrounding rocky desert (McKee, 1979; Meissner et al., 1989; Wallace et al., 1997).

In the north of Al-Jawf a set of semi-parallel treading faults and minor graben systems, oriented slightly perpendicular to the Wadi as-Sirhan graben, have greatly influenced local topography and exposed lithologies. The block faulting has segregated the study area into a set of micro regions with highly variable terrain. In this area, the exposed bedrock consists of continental to marine clastics, fine to medium-grained sandstone, with thin shales of interbedded layers. The region also has stromatolithic creamy limestone and yellowish semi-consolidated limestone rocks with interbedded layers of shale, silt or gypsum (Wallace et al., 1997). A great range of siliciferous minerals, mostly chert and flint, are found within the different limestone units across the sector. During the survey activities these areas were targeted and in the majority of cases proved to be of archaeological interest. Within the Tertiary rock units, four lithologies have suitable lithic raw materials. These occur either as dispersed chert nodules or continuous chert bands within the Paleocene to Eocene rock strata (Meissner et al., 1989; Wallace et al., 1997).

The sites presented in this paper come from three different areas sampled during the 2013 and 2015 field campaigns. Areas 1 and 2 are located in the north of the Al-Jawf quadrangle and are situated on the Jol Ajrubah, a large horizontal plateau dissected by minor faulting and small drainages. Survey area 1 encompasses the sandstone portion of the plateau, which is characterized by a large, now dry, drainage system that cuts through the soft sandstone. The topography on top of the sandstone plateau is variable; the highest zones are composed of flat surfaces, while towards the drainage system topography becomes increasingly rough and surfaces are composed of large sandstone blocs found on moderate to steep slopes. Area 2 is located to the north of area 1 (still on the Jol Ajrubah) and is situated some $100 \mathrm{~m}$ higher and shows a different lithology. In this area beige bioclastic limestone forms the predominate portion of the exposed bedrock. Low step zones with flat surfaces characterize the topography on the limestone plateau; slopes are very steep and generally coincide either with drainage systems or faults in the area. Area 3 is located in the At-Tawil escarpment situated within the Nefud desert. Sandstone ridges and inselberg chains surrounded by large eolian plains dissected by small drainages characterize this escarpment. Survey activities in area 3 targeted the top of one sandstone ridge in the southeast of the At-Tawil escarpment.

\section{Methods}

Prior to this study, the Al-Jawf province had undergone only cursory surveys (Adams et al., 1977; Parr et al., 1978). In the present study, surveyed locations were chosen based on analyses of satellite imagery that helped assess obstacles along the terrain and accessibility by car, as well as geological maps, which helped identify chert/flint beds and raw material outcrops in the area. Walking transects were placed along prominent landscape features such as drainage systems, grabens, plateaus and stable surfaces in general. Lithic scatters found along those walking transects were recorded using a handheld GPS and named by the acronym DAJ (for 'Dumat al-Jandal'). Information on site location and distribution, artifact density, raw material availability and the presence of, and proximity to, outcrops was recorded. Information on the artifacts weathering and size were recorded, as well as a preliminary attribution to one of the broad Paleolithic chronological units (Lower, Middle or Upper). Artifact sampling methodology at the sites consisted either of collecting all visible archaeological material, 


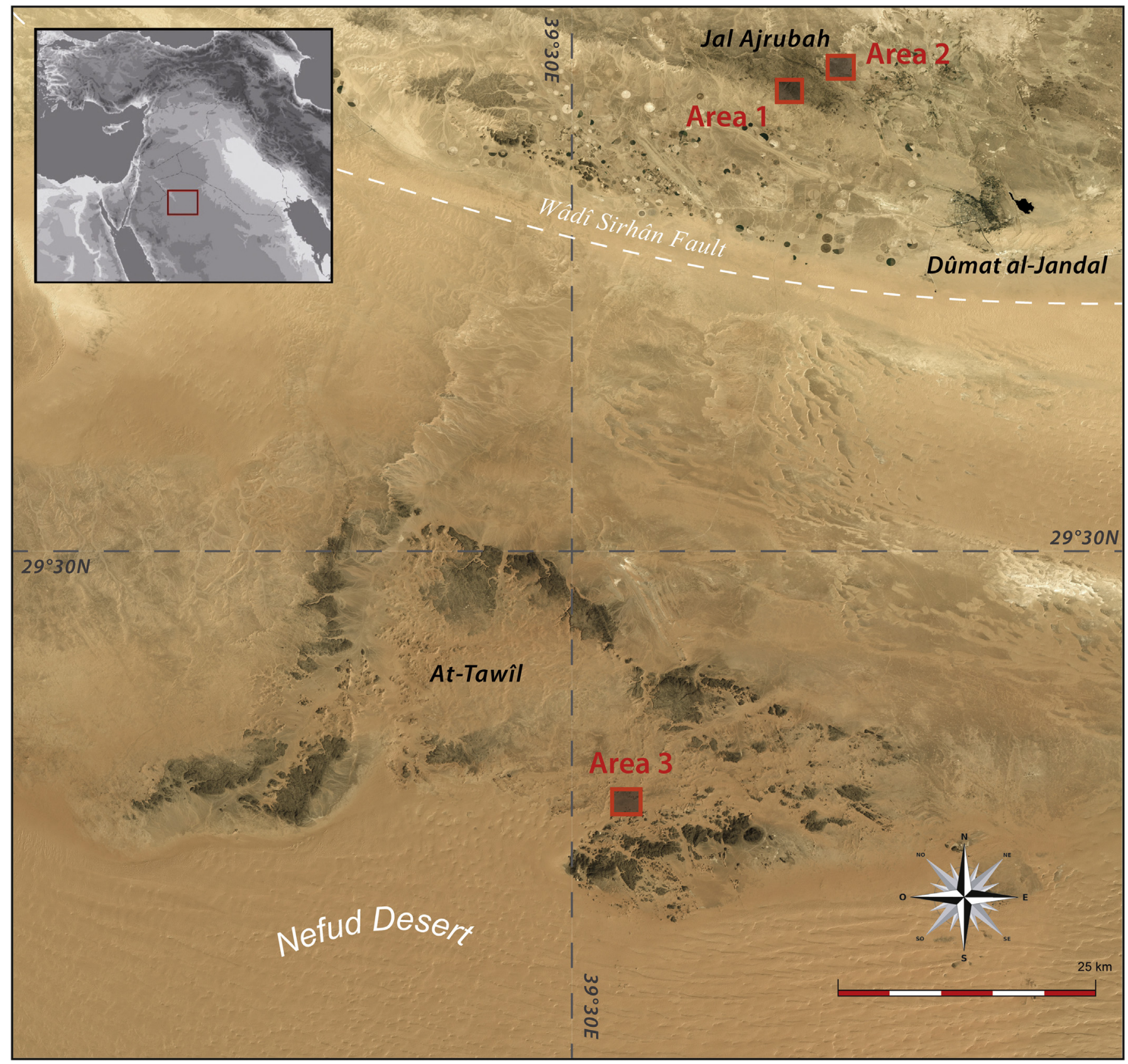

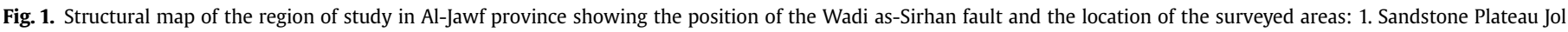
Ajrubah area; 2. Limestone Plateau Jol Ajrubah area; 3. At-Tawil area.

which were effectuated as sites with low sample size, or selective samples (targeting cores and diagnostic debitage) in the cases of large and dense sites. The collected samples were analyzed using a methodology developed for describing variability among Middle Paleolithic Levallois assemblages based on previous work (e.g. Van Peer, 1992; Boëda, 1994, 1995; Meignen, 1995; Monigal, 2002; Crassard and Hilbert, 2013; Usik et al., 2013). Artifacts were classified into types including cores, debitage (encompassing all byproducts of knapping activities) and tools. Maximum length, width and thickness were recorded for cores and Levallois debitage (following the flaking axis); flakes and core preforms (pieces with less than four visible removals) were attributed to a size module. Scar pattern, butts, state of preservation and amount of cortex were recorded as regards debitage. For the Levallois cores, striking platform characteristics were recorded, as well as orientation of dorsal preparation scars, shape of core and shape of preferential flake. Raw material type was also recorded, although gray chert was found to be widely used, gray and dark brown banded chert, and dark and gray quartzite (Fig. 2), were also knapped when available.

Nubian cores exhibit specific morphologies that become evident through particular technological criteria, such as the configuration of the distal platform and specific Levallois surface (or dorsal) preparation. In this study, we differentiate among three different types of Nubian preparation: cores that present Nubian type 1, type 2 and type $1 / 2$ preparation. For a detailed description of each preparation type see Crassard and Hilbert (2013) or Usik et al. (2013): suffice to say that each type presents a specific approach to the preparation of the distal to mesial portion of the Levallois 

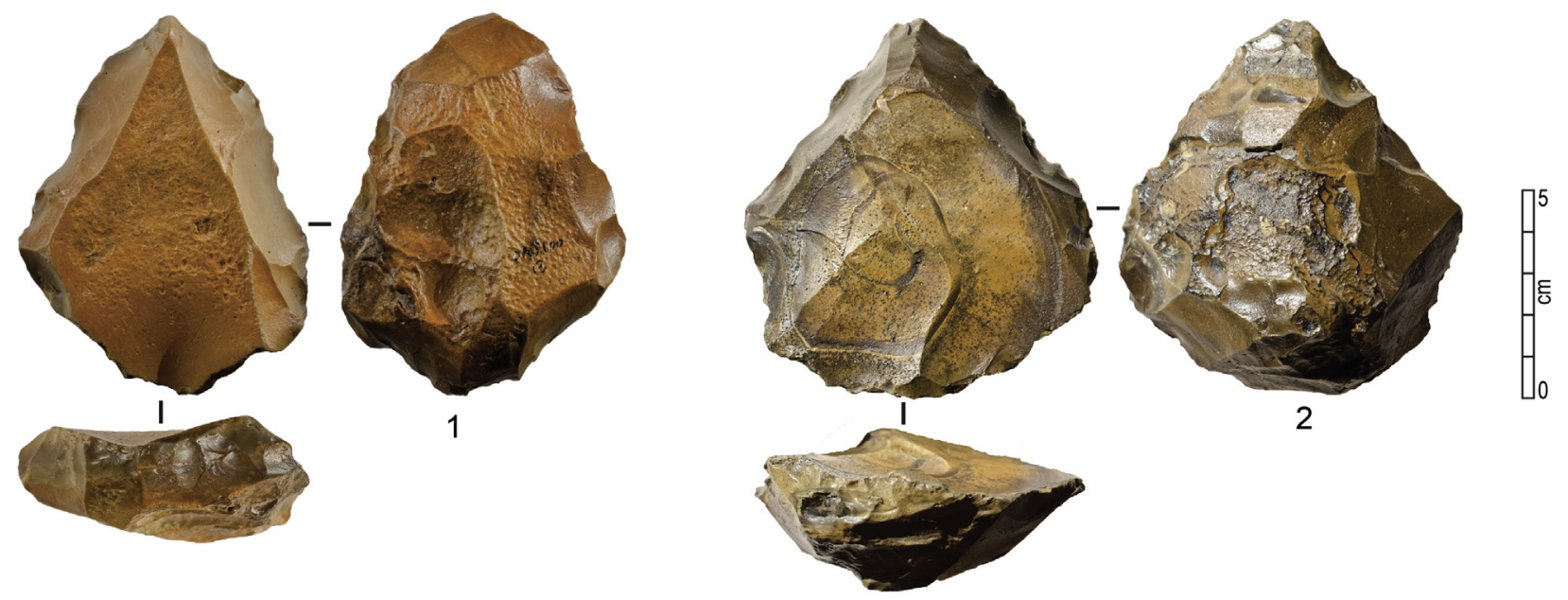

2
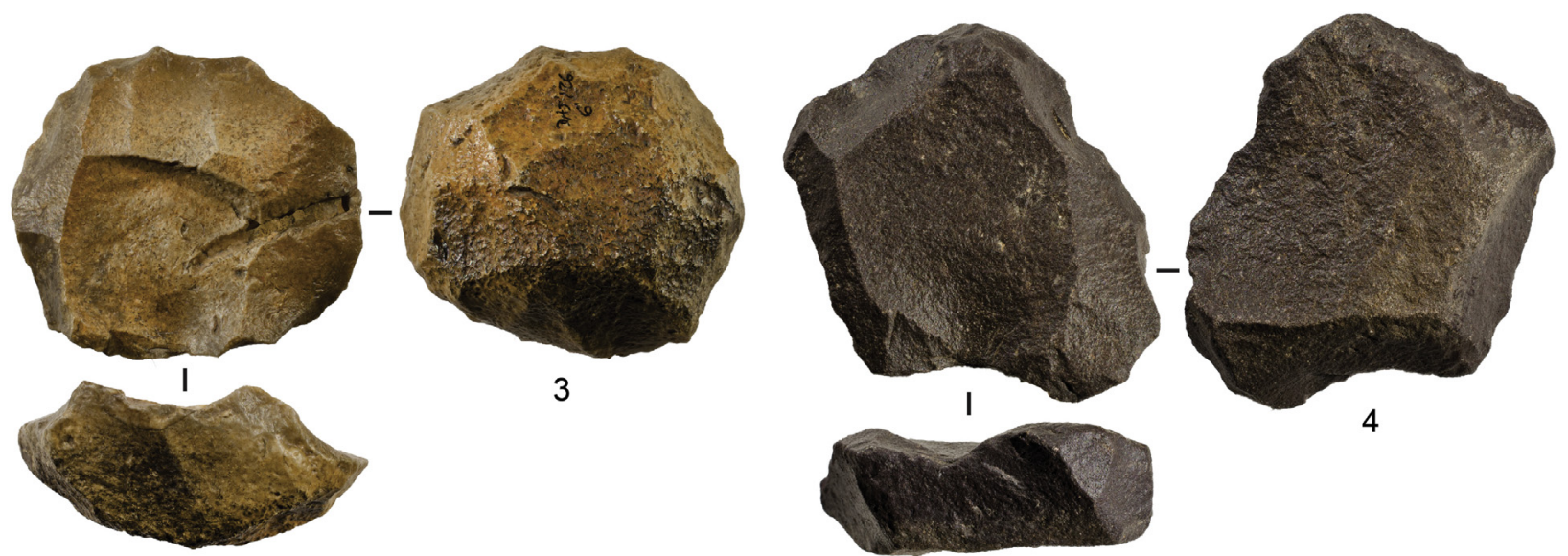

3

4

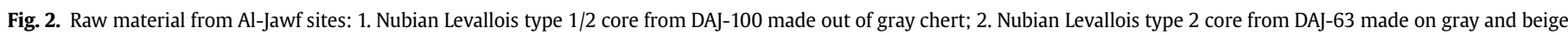
banded chert; 3. Levallois Preferential core from DAJ-126 made out of gray quartzite; 4. Levallois preferential core from DAJ-97 made out of dark quartzite.

surface by either two distal divergent removals (type 1 ), distal convergent and bilateral removals (type 2 ) or a combination of both (type 1/2). Usik et al. (2013) have drawn attention to the importance of characterizing the distal platform angle (DPA) and the medial distal ridge cross-section (MDRC) on Nubian cores. These aspects of core morphology serve to distinguish Nubian technology from other Levallois Point producing systems. Additionally, we have classified cores in terms of preparation methods that reflect the directionally of the removals used to shape and arranged the Levallois surface, these are: unidirectional, unidirectional crossed, bidirectional, bidirectional crossed, bilateral, distal unilateral, distal bilateral and centripetal (Fig. 3).

\section{Results}

During survey activities, 48 sites have been attributed to the Middle Paleolithic based on the presence of Levallois technology and weathering state of the artifacts. Middle Paleolithic sites were of low artifact density (one to four pieces per square meter) and small in size, generally not exceeding 100 square meters of total surface. Collection activities targeted all cores found at each site, which provide a large amount of technical information on the last phases of flaking, as well as Levallois flakes, points and debordant elements. In terms of technological variability, reduction patterns found at the Al-Jawf Middle Paleolithic sites exhibit primarily preferential Levallois. Of the 48 Middle Paleolithic sites, ten assemblages from ten different sites were selected for presentation here, given their sample size and the presence of Levallois cores.

\subsection{Area 1, the Sandstone plateau (Jol Ajrubah)}

The sites found during the survey of area 1 on the sandstone plateau of the Jol Ajrubah area were located in the general vicinity of a large wadi with many smaller tributaries (Fig. 4), which had cut their way through the Early Devonian sandstone (Tawil Formation). No primary chert outcrops were identified in the immediate proximity of sites DAJ-110, DAJ-120, DAJ-122 and DAJ-123. Inside aggregation terraces and sediment bars located within the large wadi itself. However, medium to large sized $(10-30 \mathrm{~cm}$ maximum diameter) gray chert nodules were found in secondary position. The large wadi and its tributaries cut through the sandstone and limestone portion of the plateau, the latter being located towards the northwest approximately three kilometers away from the sites. Survey of the limestone areas on the plateau revealed numerous primary chert outcrops; it is likely that the chert nodules found in secondary position within the large wadi in survey area 1 had been transported by the fluvial system from the limestone plateau. On some areas on top of the plateau, heavily weathered gray quartzite cobbles and dark quartzite blocks were also found. While knappable, these raw materials were not used as intensively as was the chert. 


\section{Preparation of Levallois (Dorsal) core surface}

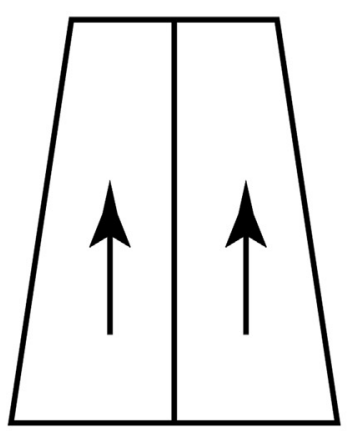

Unidirectional

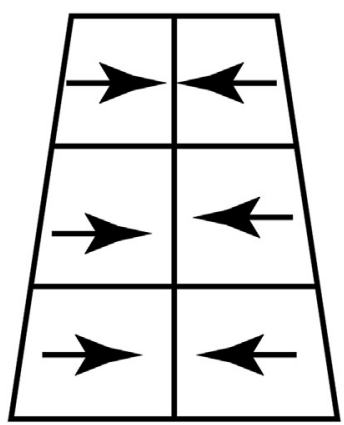

Bilateral

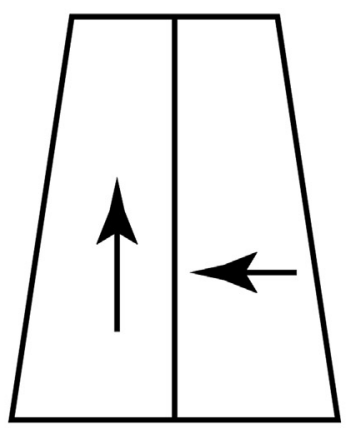

Unidirectional Crossed

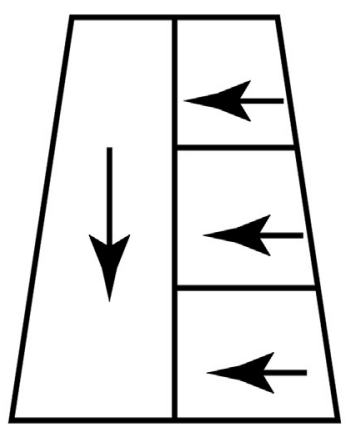

Distal Unilateral

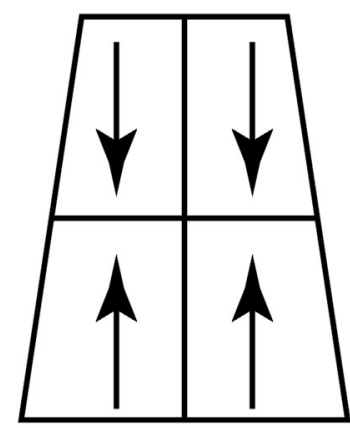

Bidirectional

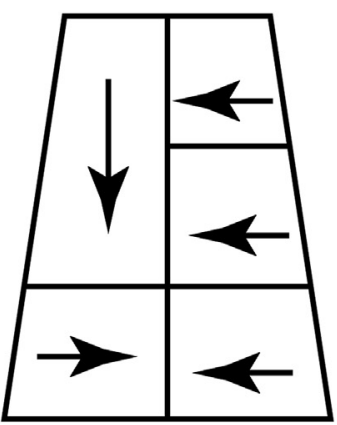

Distal Bilateral

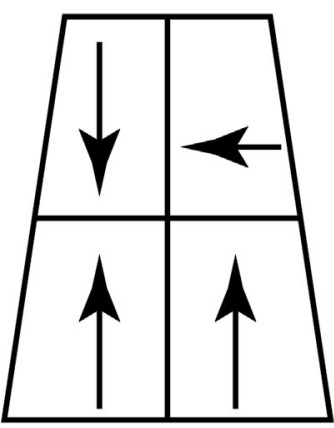

Bidirectional Crossed

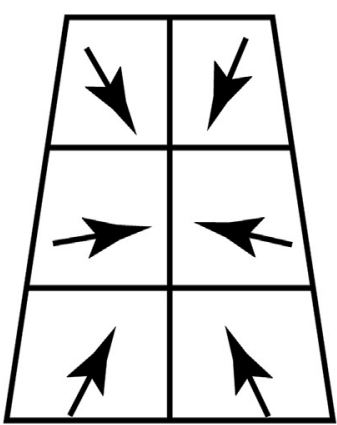

Centripetal

\section{Median Distal Ridge Cross-Section}

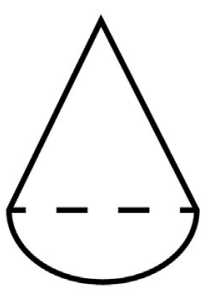

Steep $<60^{\circ}$

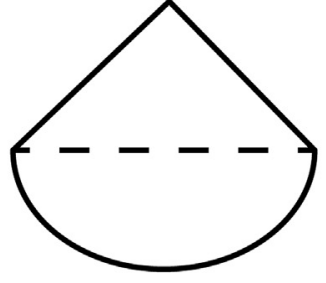

Semi-steep $60^{\circ}-90^{\circ}$

\section{Distal Platform Angle}

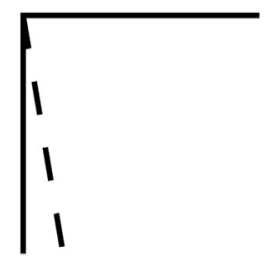

Right $90^{\circ}-80^{\circ}$

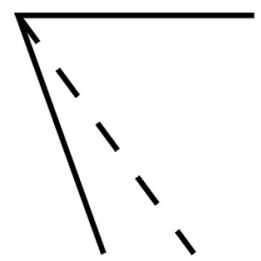

Semi-acute $80^{\circ}-60^{\circ}$

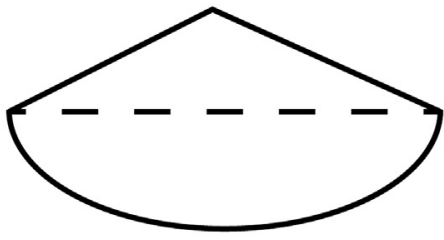

Oblique $90^{\circ}-120^{\circ}$

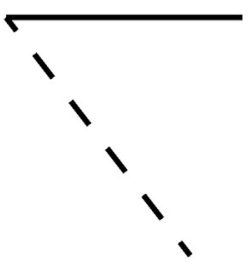

Acute $<60^{\circ}$

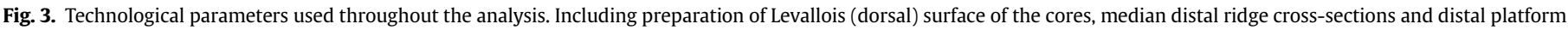
angle (MDRC and DPA modified after on Usik et al., 2013, fig. 3). 


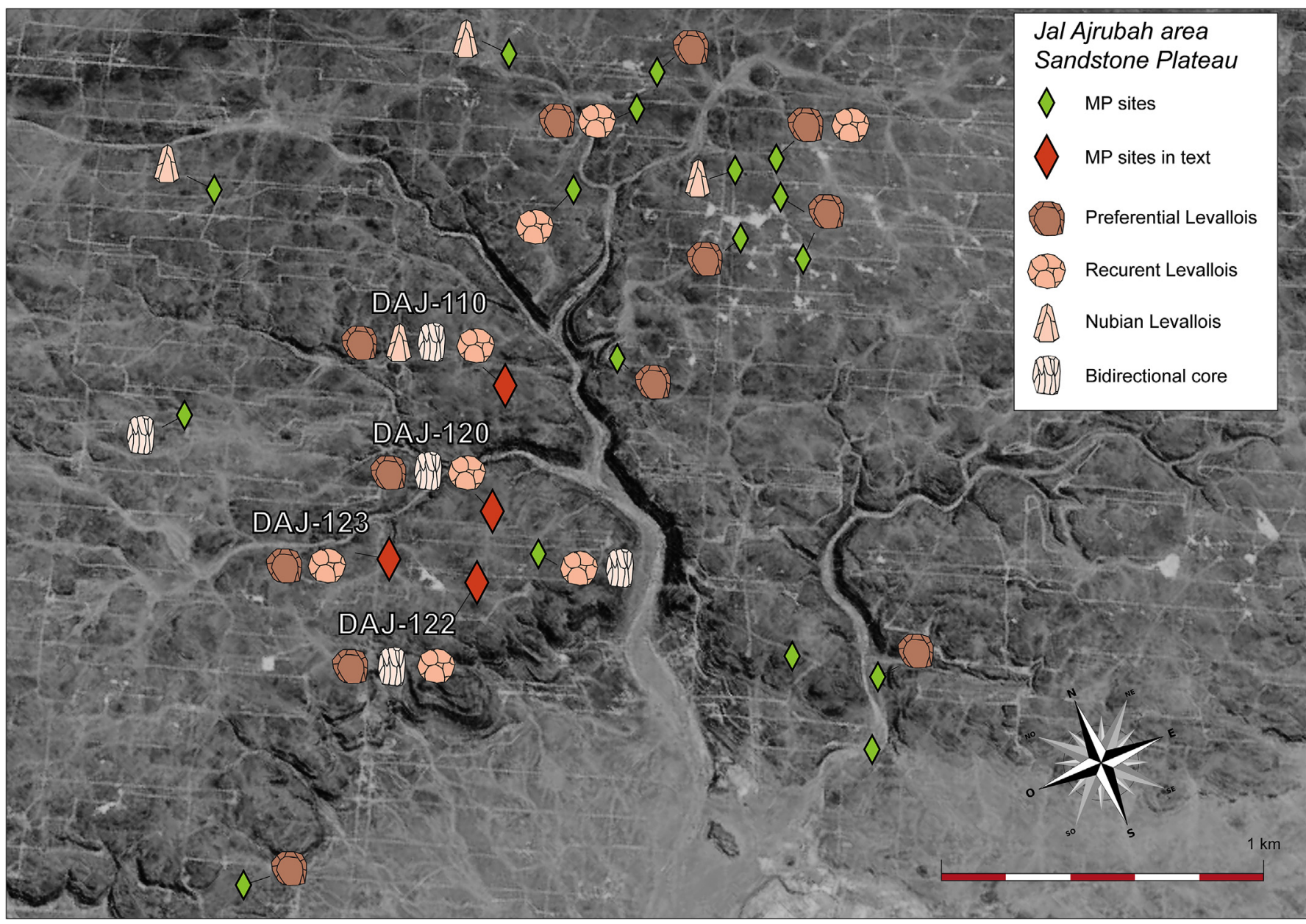

Fig. 4. Area 1, Jol Ajrubah sites (Sandstone Plateau): location of the Middle Paleolithic sites and the core types found at each locality.

DAJ-110 is located on top of the sandstone plateau overlooking both the plain to the south and the confluence of two wadi tributaries. Middle Paleolithic artifacts were found on a slight slope and on a flat surface. Artifacts density varies between low to moderate, with four to ten artifacts per square meter within the densest area of the site, which is located at the highest point on this part of the plateau within a ten square-meter depression. Some cores and flakes were found five meters further down slope, towards the lower portion of the plateau, within a small gully that runs towards the large wadi. Artifact density outside of the ten square meter area of the site was low, with only one to three artifacts per square meter. Sampling was restricted to the densest ten square-meters of the site and targeted cores and diagnostic debitage; a total of 122 pieces were collected and analyzed (Table 1). No raw material source was identified on or close to the site; all artifacts were made on gray chert. Levallois $(\mathrm{n}=26)$ and non-Levallois $(\mathrm{n}=8)$ cores were recovered and analyzed (see Supplementary Information for detailed technological analysis of the lithic samples). Non-Levallois cores encompassed bidirectional, multiple platform and undifferentiated cores. Levallois preferential cores were shaped by bidirectional, bidirectional crossed and distal unilateral preparation; Nubian cores were reduced by bidirectional and bilateral variations of Levallois surface preparation. Medial ridge cross section (MRCS) and distal platform angles (DPA) analyzed on the five Nubian cores from DAJ-110, show homogenous results: DPAs were semi-acute in all cases, while MRCS varied between steep $(\mathrm{n}=1)$, semi-steep $(\mathrm{n}=3)$ and oblique $(\mathrm{n}=1)$. Cores are small, show a dark brown patina and rounded edges. Debitage found at the site is also small and show technological characteristics comparable to those observed on the cores. No variability in terms of raw material usage was detected.

DAJ-120, DAJ-122 and DAJ-123 are located on the western terrace overlooking the wadi and the plain in front of the plateau. Similar to DAJ-110, the sites were located within flat depressions on top of the plateau; no raw material outcrop could be detected in the vicinity of the sites. A total of 147 artifacts were collected and analyzed from these three sites (Table 1 ). Of these, DAJ-120 shows the lowest find density (0-1 artifact per square meter); the lithic scatter encompasses a 30-m radius. A small collection was made consisting of 13 cores and 16 pieces of debitage; cores show a high variability in terms of the preparation of their dorsal surfaces. Levallois preferential cores show unidirectional and bidirectional variations of preparation, as well as centripetal preparation; two centripetal recurrent Levallois cores were also found at DAJ-120.

DAJ-122 and DAJ-123 are of high density, with over ten pieces per square-meter at their densest spots. The sites vary in size, DAJ122 having a 30-m radius in which artifacts were found, while DAJ123 spreads across a 100 by $40 \mathrm{~m}$ area. The predominant core types found at DAJ-122 were Levallois preferential and Levallois recurrent centripetal cores. The majority of artifacts were made on gray chert, two cores, however, were made on the locally available gray quartzite; one of them was a bilaterally prepared Levallois preferential core, while the other one was a core preform which had only two flakes detached form a flat surface. No difference in 
Table 1

Core and debitage types from the ten selected Al-Jawf sites.

\begin{tabular}{|c|c|c|c|c|c|c|c|c|c|c|}
\hline & DAJ-110 & DAJ -120 & DAJ-122 & DAJ-123 & DAJ-50 & DAJ-51 & DAJ-133 & $\mathrm{DAJ}-135$ & DAJ-98 & DAJ-100 \\
\hline Non-Levallois cores & 8 & 1 & 13 & 4 & 1 & 4 & & 4 & 4 & 3 \\
\hline Single Platform & & & & 1 & & 2 & & & & 1 \\
\hline Multiplatform & 1 & & & & & & & & & \\
\hline Bidirectional opposed & 2 & 1 & 2 & & 1 & 2 & & & 2 & 1 \\
\hline Bidirectional crossed & 1 & & 1 & & & & & & & \\
\hline Two debitage surface & & & & & & & & 1 & & \\
\hline Undifferentiated & 4 & & & & & & & & & \\
\hline Core preform & & & 10 & 3 & & & & 3 & 2 & 1 \\
\hline Levallois cores & 26 & 12 & 25 & 29 & $\mathbf{9}$ & 15 & 6 & 11 & 8 & 4 \\
\hline Preferential with centripetal prep. & & & 2 & 3 & & 2 & 1 & & & 1 \\
\hline preferential point & & & & & 1 & & & & & \\
\hline preferential other & 9 & 6 & 9 & 13 & 1 & 7 & 2 & 5 & 6 & 2 \\
\hline centripetal recurrent & 4 & 2 & 5 & 2 & & & 1 & & 1 & \\
\hline Nubian Type 1 & 1 & & & & 2 & & & 2 & 1 & 1 \\
\hline Nubian Type 2 & 3 & & & & 3 & 2 & & & & \\
\hline Nubian Type $1 / 2$ & 1 & & & & 1 & 1 & & & & \\
\hline preform/Facial & 8 & 4 & 9 & 11 & 1 & 3 & 2 & 4 & & \\
\hline Debitage & 88 & 16 & 20 & 27 & $\mathbf{0}$ & 3 & 22 & 9 & 17 & 8 \\
\hline Flake & 42 & 4 & 4 & 5 & & & 7 & 2 & 8 & 6 \\
\hline Blade & & 2 & 1 & 3 & & & & & 1 & \\
\hline Levallois point & 2 & 1 & & & & 3 & & 1 & & \\
\hline Levallois preferential flake & & & & 6 & & & 1 & & 1 & \\
\hline Levallois flake & 20 & 7 & 5 & 9 & & & 10 & 1 & & \\
\hline Levallois debordant & 9 & & 4 & 0 & & & & & & \\
\hline Debordant element & 15 & 2 & 6 & 4 & & & 4 & 5 & 7 & 2 \\
\hline Total & 122 & 29 & 58 & 60 & 10 & 22 & 28 & 24 & 29 & 15 \\
\hline
\end{tabular}

preparation could be observed between the two raw material types. In general, the cores from DAJ-122 were predominantly prepared using centripetal and bidirectional methods of preparation.

DAJ-123 yielded a comparable assemblage to that of DAJ-120 and DAJ-122, Levallois preferential cores were the most common type found at the site (Table 1). Two kinds of chert were used at the site, both showing similar knapping properties; no discernable raw material selection could be identified. A small number of flakes and core preforms were made on gray quartzite. Similar to the other sites in the area, bidirectional and centripetal scar patterns were found to prevail dorsal surface configurations of Levallois cores.

\subsection{Area 2, the Limestone plateau (Jol Ajrubah)}

The survey area 2 was located three kilometers to the west of a small village of Ajrubah, its surroundings were characterized by intensive agricultural use, resulting in a highly altered landscape marked by construction and planification activities. The plateau, composed of Tertiary limestone of the Jalamid Formation, contains numerous chert outcrops; these have been surveyed by the authors and have, in most cases, yielded archaeological material. The sites in this area were found on top of the limestone plateau, on the foot of the plateau on low terraces overlooking the drainage system and within the drainage systems themselves (Fig. 5); four of these sites will be presented in detail here (DAJ-50, DAJ-51, DAJ-133 and DAJ135). DAJ-50 and DAJ-51 were located on top of the limestone plateau on flat desert pavement composed of limestone debris and in some areas chert nodules; the sites were only $160 \mathrm{~m}$ away from each other. Both sites have a low density of artifacts (Table 1), these being made of gray chert and quartzite showing moderate to highly weathered surfaces. A chert outcrop was identified in close proximity to DAJ-50 and DAJ-51. DAJ-133 is located on a low limestone ridge on top of a plateau in the western part of the area. Heavily weathered gray quartzite blocks were found across the elevated areas and depressions on this plateau; no chert outcrops were found in this area; nevertheless, artifacts are made of gray chert and are heavily weathered, showing a dark brown patina and rounded edges. Artifact density is moderate, with four to ten pieces per square meter in the densest part of a 30 by $50 \mathrm{~m}$ area. DAJ-135 is located on a low terrace close to the piedmont of the limestone plateau overlooking a drainage system that makes its way through the Al-Wadi Graben. The site was found directly on a chert outcrop with medium to small size nodules $(8-20 \mathrm{~cm})$. Artifacts were found in low density across a 30-60 $\mathrm{m}$ area (Table 1 ).

A total of 32 chert artifacts were collected from DAJ-50 and DAJ-51 (Table 1). These two assemblages will be described together due to their proximity, the fact that they were found associated with the same raw material outcrop and the technological and typological similarities between them. Nubian Levallois and Levallois preferential cores were found at both these sites (Table 1). General core shapes at DAJ-50 were predominantly triangular, while at DAJ-51 ovoid forms prevail. Levallois cores show predominantly bidirectional, bidirectional crossed and centripetal dorsal preparations; cores are generally small, not exceeding $80 \mathrm{~mm}$ in maximum diameter. MDRC and DPA characteristics on Nubian cores from both sites were similar with both assemblages showing a tendency towards oblique MDRC and acute to semi-acute DPA.

At DAJ-133, 28 gray chert artifacts were collected and analyzed (Table 1); the six cores were classified as preferential Levallois (no Nubian cores were found), preferential Levallois with centripetal preparation, recurrent preferential Levallois and Levallois preforms. The preferential Levallois cores display bidirectional and unidirectional-crossed dorsal preparations, while the preforms show unidirectional convergent dorsal preparation. A total of 24 artifacts were collected and analyzed from DAJ-135 (Table 1), 15 of them being Levallois cores, showing distinct methods of dorsal preparation. Nubian cores showing type 1 preparations presented bidirectional scars on the Levallois surface. A small number of Levallois preferential cores display unidirectional and bilateral scars; the majority, however, have bidirectional and bidirectional crossed preparations. As with the other sites in area 2, little variability was observed in terms of raw material usage; chert being the most common used siliceous material for knapping. 


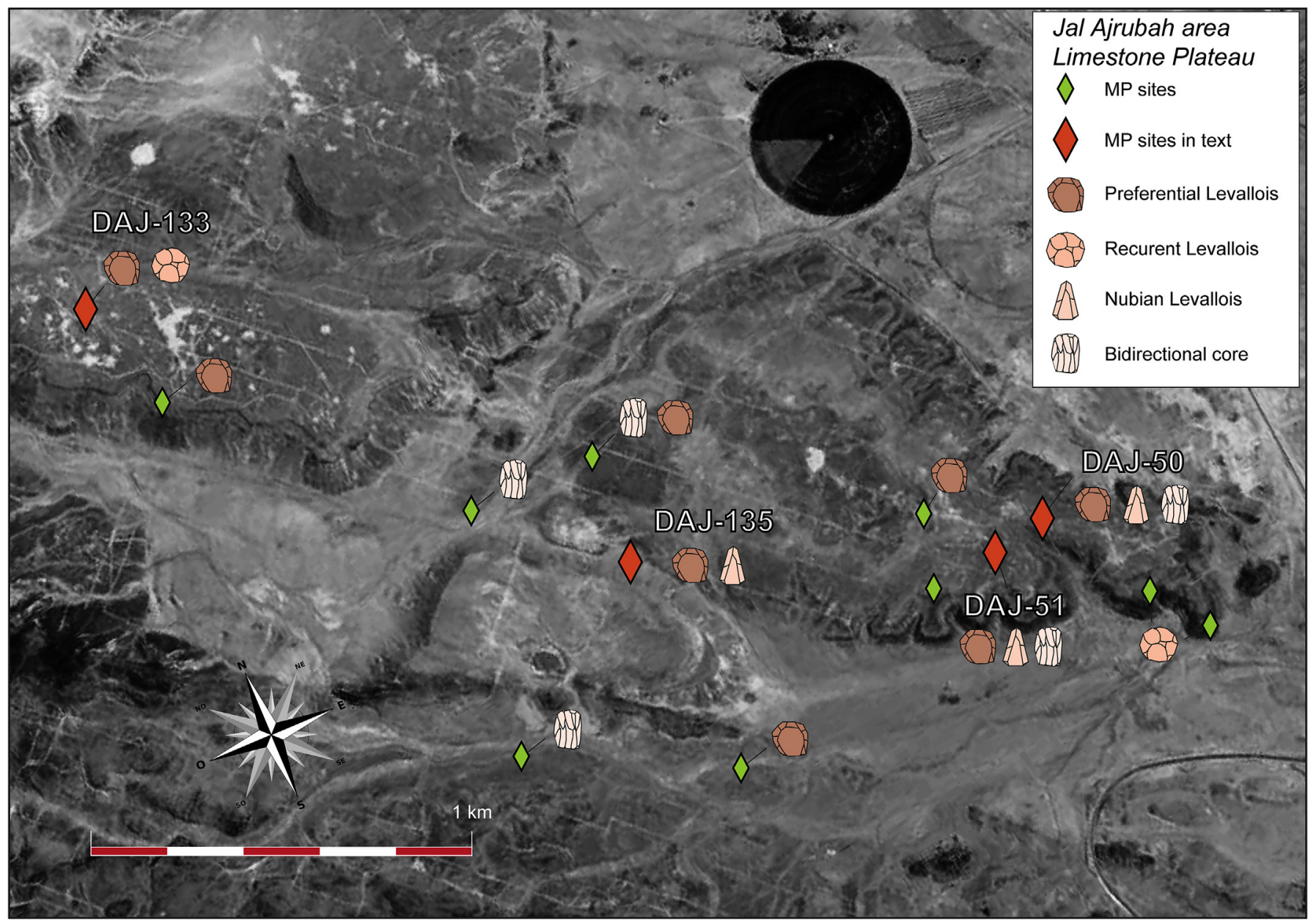

Fig. 5. Area 2, Jol Ajrubah sites (Limestone Plateau): location of the Middle Paleolithic sites and the core types found at each locality.

\subsection{Area 3, At-Tawil escarpment}

Sites DAJ-98 and DAJ-100 were found in the At-Tawil escarpment, a plateau composed of several Early Devonian sandstone jebels approximately $100 \mathrm{~km}$ south of Dumat al-Jandal (Fig. 6). Raw material is abundant across the surrounding areas of the site and was found eroding out of Tertiary limestone deposits resting on top of the sandstone. Chert nodules are medium to large in size (15-30 cm in diameter) and gray to grayish-brown in color. DAJ100 is on a low depression along the ridge of the jebel. Artifacts, all composed of gray chert, were found on a slight slope leading down the ridge. The site had a low density of artifacts (0-1 per square meter), which were distributed across a $15-\mathrm{m}$ radius flat area. DAJ-98 was located $400 \mathrm{~m}$ southeast of DAJ-100 on top of the plateau. The surface of the site was characterized by large quartzite blocks, small rock scatters and sand, artifact density across the site was low; cores and flakes were spread across a 50 square meters surface. A Tertiary chert outcrop was located close to the site. Artifacts were made of gray chert and dark red, fine grained quartzite, showing in general light weathering signs, sharp ridges and slight patina.

At both sites, cores, debitage and tools were collected and analyzed, totaling 45 artifacts (Table 1 ). Most sites found across the Al-Jawf quadrangle had a very small number of Middle Paleolithic tools, the single specimen found at DAJ-98 was classified as a $15 \mathrm{~cm}$ long quartzite flake with faceted butt, bidirectional scar pattern and straight, continuous retouch along one side. Artifacts are primarily made out of gray chert, while one Levallois preferential other core from DAJ-100 is made of banded beige and gray chert. Aside from the color difference between the raw materials, one being gray and the other gray with darker bands running through it, no evident quality disparity was observed. Preparations of Levallois cores, including the Nubian cores, were primarily bidirectional and bidirectional crossed. At DAJ-98 two specimens showed one large unidirectional scar on their dorsal surfaces. The cores with unidirectional scar patterns revealed overpassed preferential removals, which erased the distal portion of the cores, leaving one large unidirectional removal on its dorsal surfaces, thus obscuring the initial dorsal preparation. On one such core with unidirectionalcrossed preparation, a medial fragment of the preferential flake was refitted, indicating that the core was prepared in a bidirectional-crossed fashion (Fig. 7).

\subsection{Characteristics visible in the grouping of assemblages}

The ten sites presented here can be separated into four groups, based on artifact density, proximity to raw materials, core typology and the organizational systems employed for the preparation of the Levallois surfaces. Group 1 is composed of DAJ-120, DAJ-122 and DAJ-133, which are sites with medium density located far from raw material outcrops. These sites have preferential Levallois (including centripetal preparation) cores and Levallois centripetal recurrent cores (Fig. 8). Group 2 contains only one site, DAJ-123, which is far from raw material outcrops and of medium to high density, 


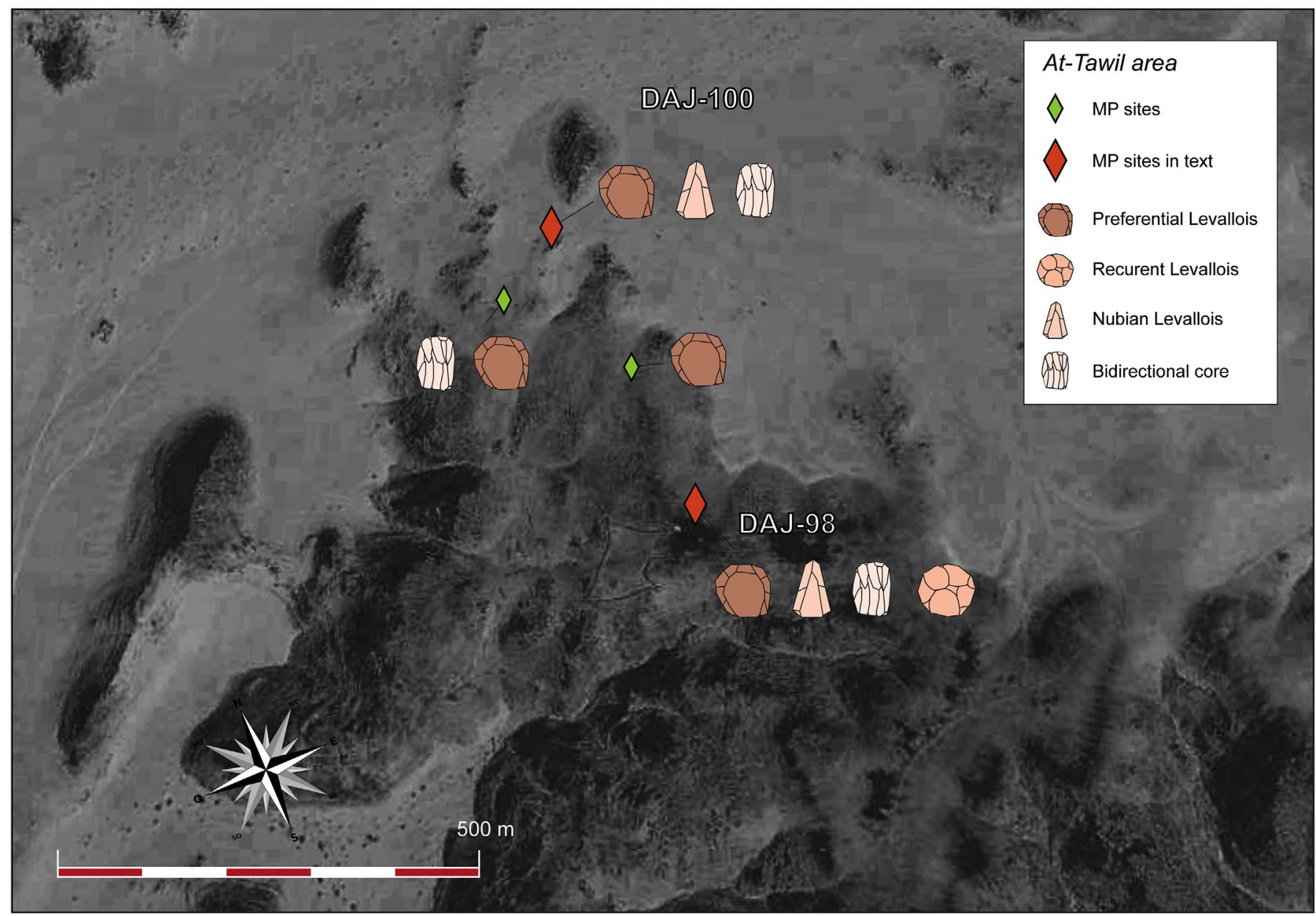

Fig. 6. Area 3, At Tawil sites. Map showing the location of the Middle Paleolithic sites in the At-Tawil area 3 and the core types found at each locality.

revealing preferential Levallois cores with primarily bidirectional and bidirectional-crossed dorsal preparations. At this site Levallois preferential flakes and Levallois flakes are larger than the cores and somewhat elongated (Index of Elongation, length divided by width, average 1.706), Levallois points and Levallois preferential flakes with triangular shapes are rare (Fig. 9).

Group 3 consists of DAJ-55, DAJ-51, DAJ-98, and DAJ-100. In this group, preferential Levallois cores with predominantly bidirectional and bidirectional-crossed dorsal preparation are accompanied by Nubian cores prepared using type, 1,2 and $1 / 2$ preparations
(Fig. 10). These sites are generally of low density and located on raw material outcrops. The last group shares the same technological characteristics with group 3 sites; it contains only one site, DAJ-110. This site is of particular interest given that it is not on a source of raw material and has medium artifact density. Raw material was brought to the site and knapped. Given its distance from known raw material sources it is expected that the DAJ-110 assemblage reflect the product of a single knapping event conducted by one group, as opposed to a palimpsest. Nubian cores are few and accompanied by flat bidirectional cores, Levallois centripetal
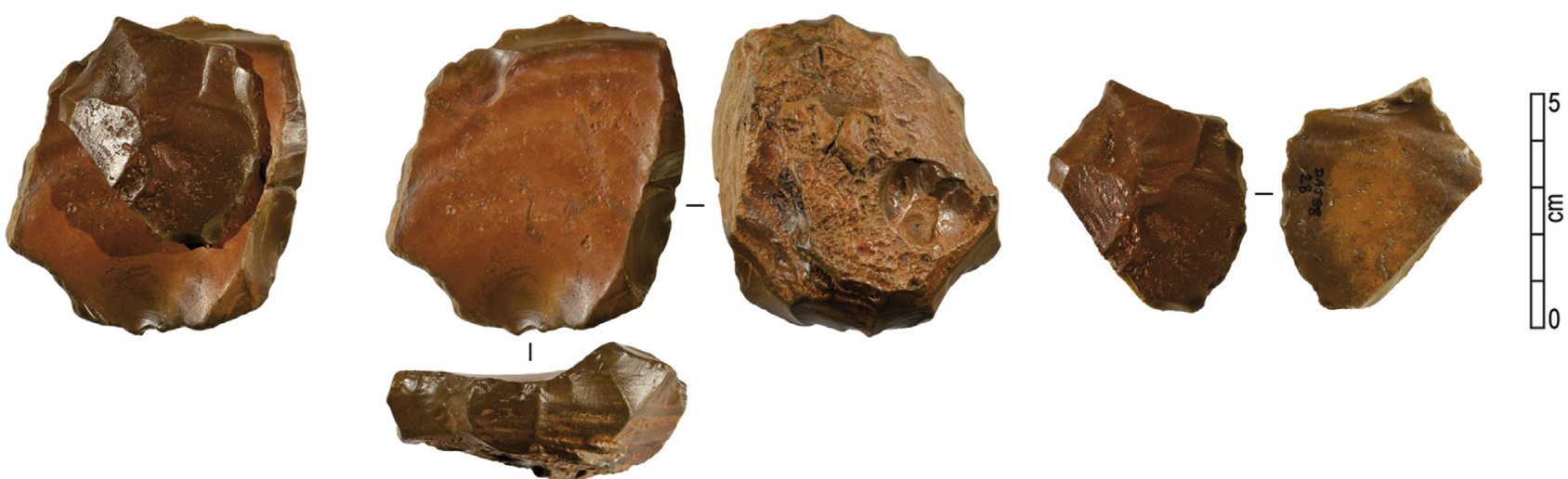

Fig. 7. Refitted fragment of a Levallois preferential flake on a preferential Levallois core. 

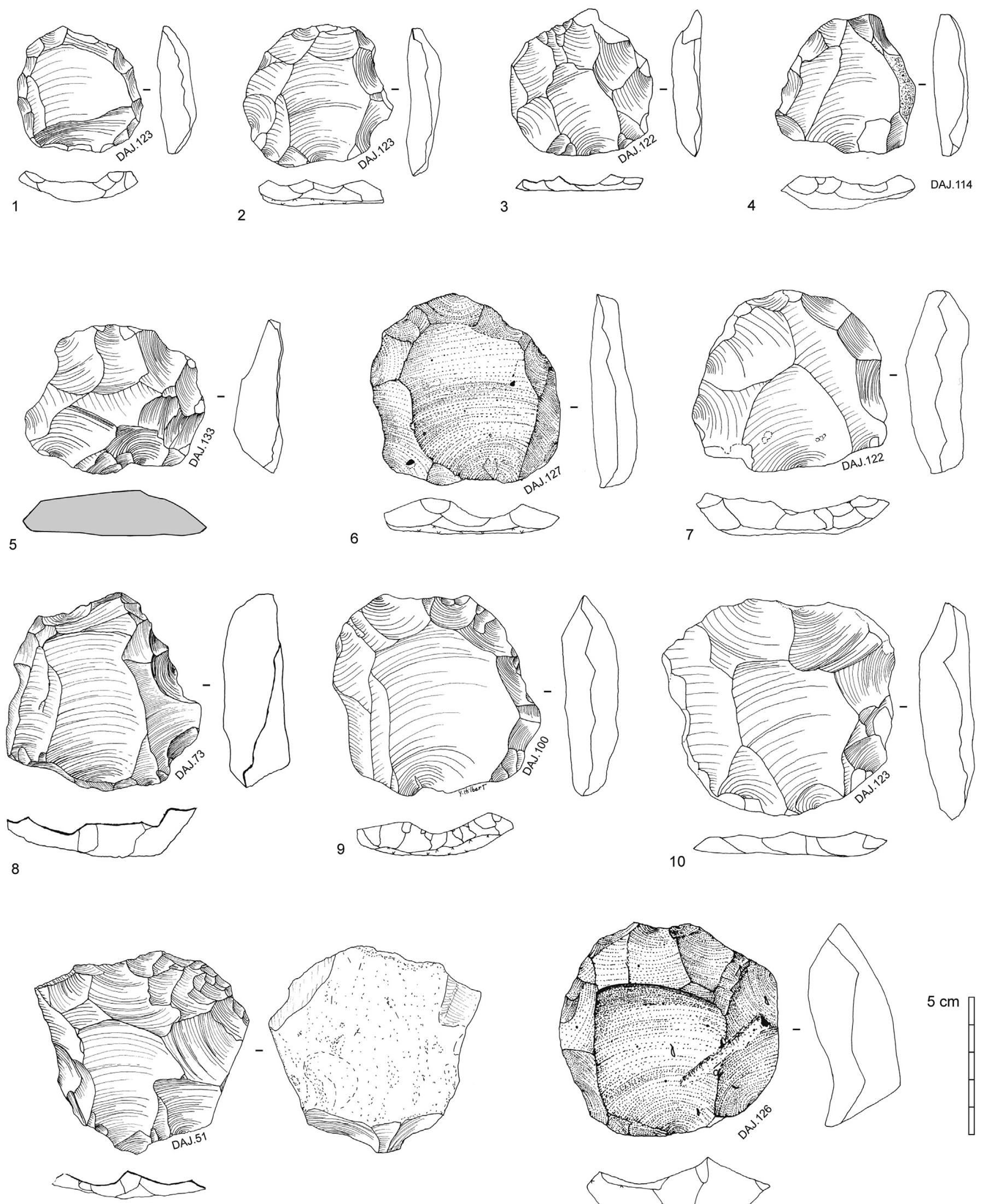

$5 \mathrm{~cm}$

11

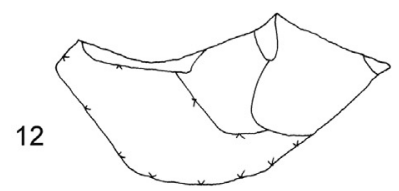

Fig. 8. Levallois preferential and recurrent cores from Al-Jawf. Levallois preferential cores with centripetal preparation: $1-3,6-9,11$. Levallois recurrent centripetal: 5 . Levallois preferential with bidirectional crossed preparation: 4, 10 and 12 . 


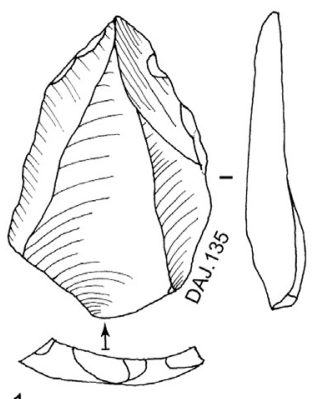

1

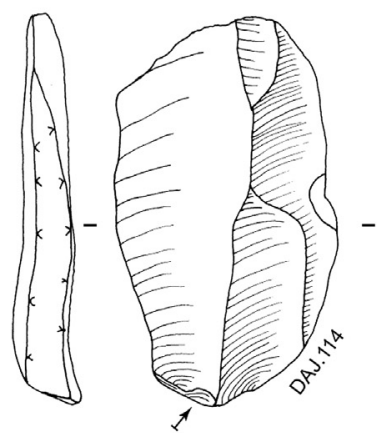

5

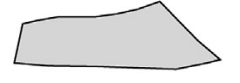

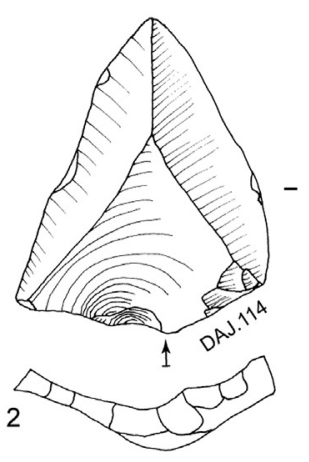
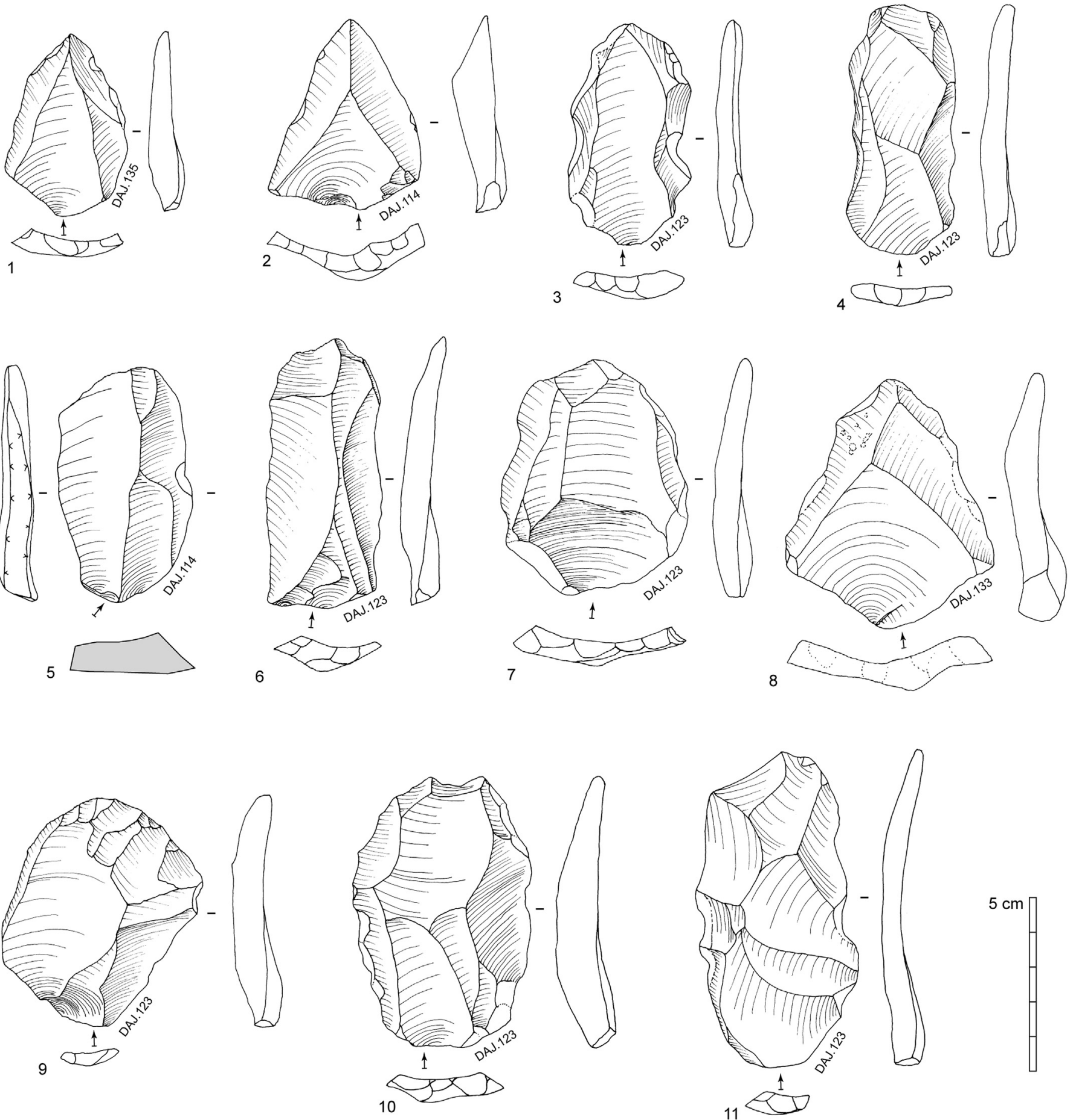

$5 \mathrm{~cm}$

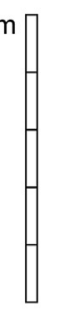

Fig. 9. Levallois debitage from Al-Jawf. Triangular Levallois end products: 1-3, 8. Levallois preferential flakes: 4, 6, 7, 9-11. Debordant element: 5.

recurrent and preferential Levallois cores with bidirectional preparation. Bidirectional opposed cores (Fig. 11) were also found in the majority of the here analyzed assemblages.

\section{Discussion}

Several studies of inter-site technological variability between assemblages from the Near East, Africa and Arabia have been published in recent years and provide valuable data on regional patterning of lithic technology (e.g. Rose and Marks, 2014; Scerri et al., 2014; Groucutt et al., 2015a). Assemblages containing Levallois preferential cores and recurrent Levallois cores have been found across North Africa, the Near East and Arabia (e.g. Shea, 2003; Hovers, 2009; Armitage et al., 2011; Petraglia et al., 2012; Scerri et al., 2014; Bretzke, 2015). In the Near East, these have been attributed to different Levantine Mousterian industries (e.g. Bar-Yosef, 1980; Marks, 1992). The sites of Hummal and Umm el Tlel in the El Kowm Basin in Syria revealed preferential Levallois reduction showing bidirectional dorsal preparation for the production of large preferential end products. The Lower Mousterian 

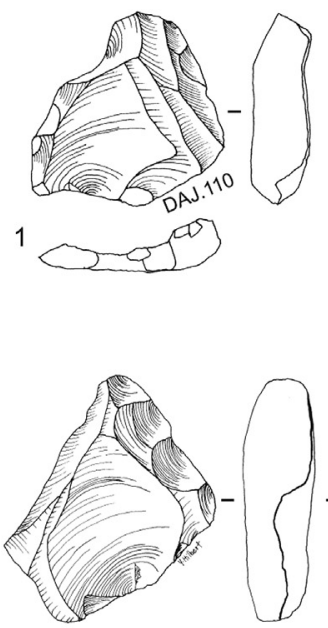

5

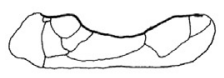

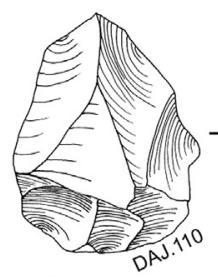

2
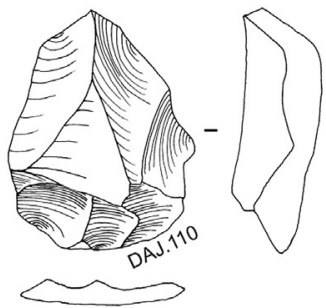

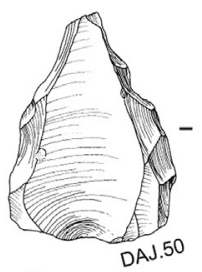

3

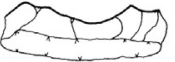

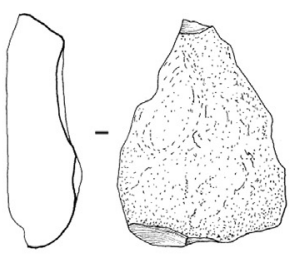

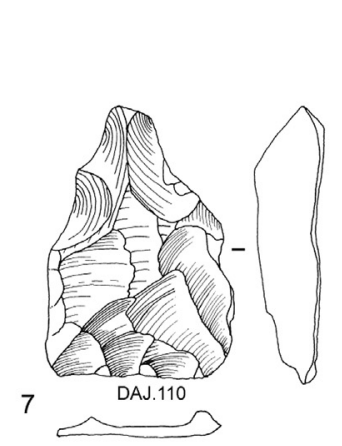

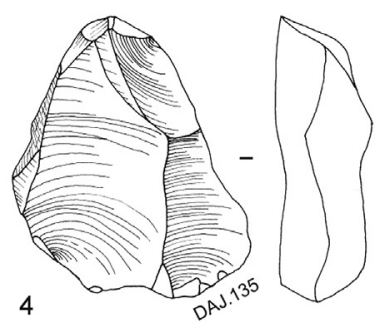

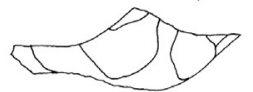

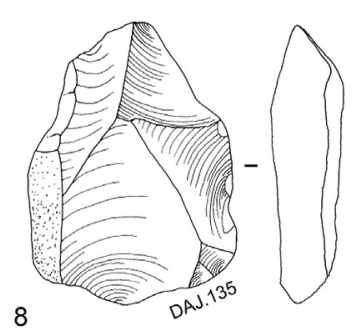

8
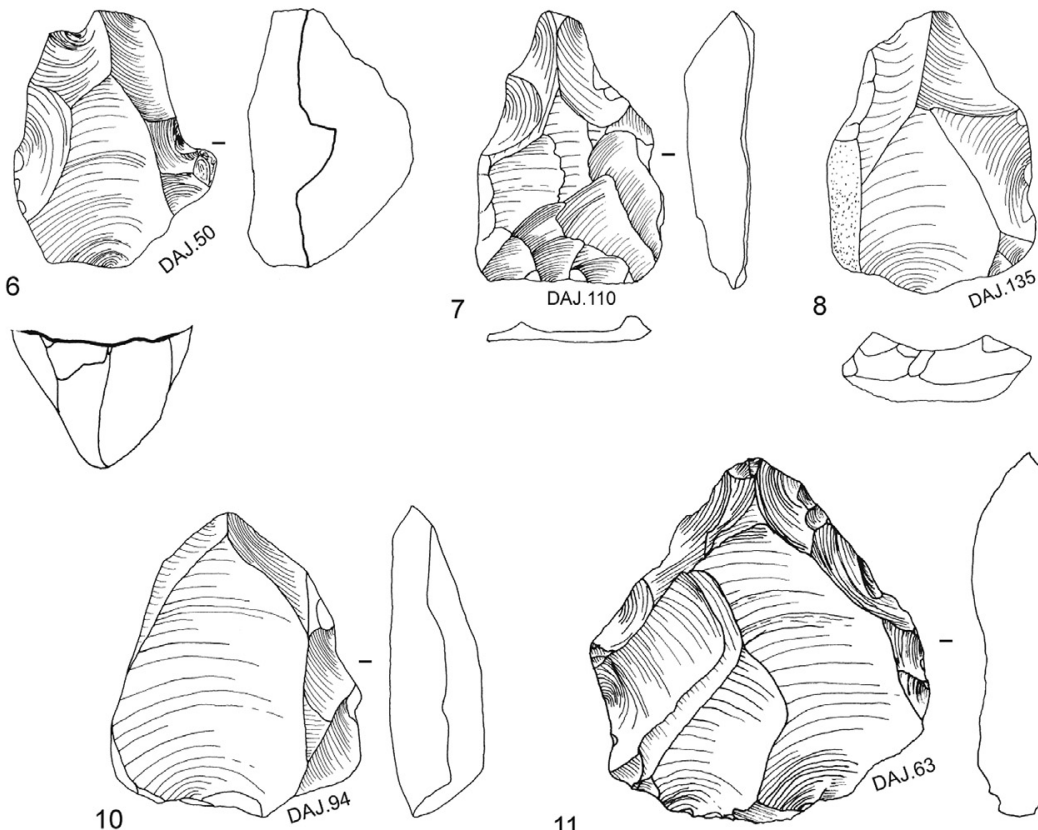

11
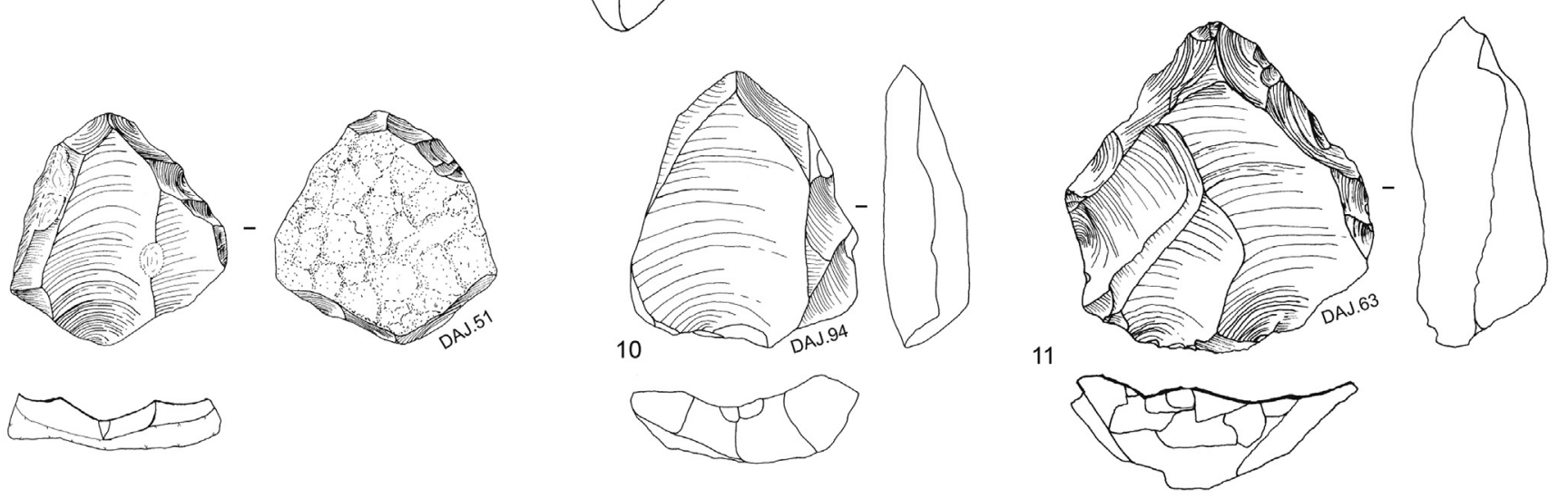
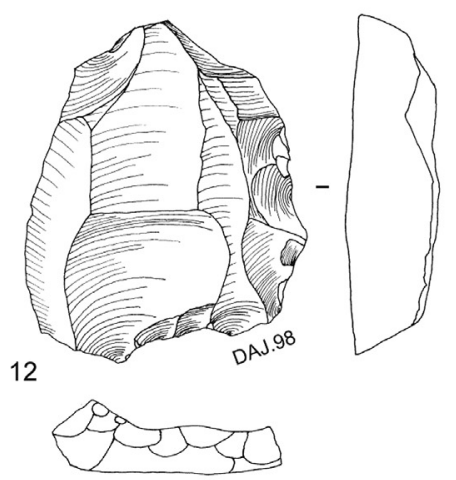
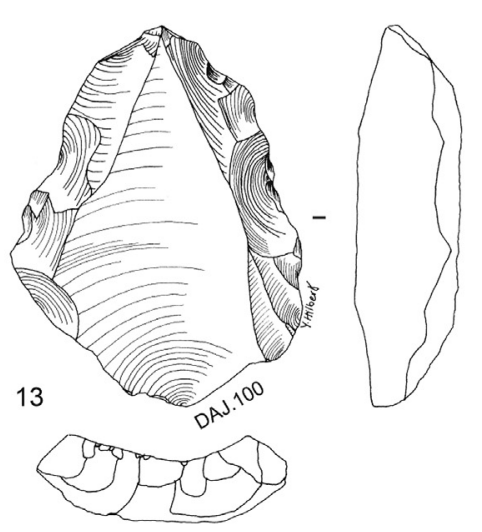

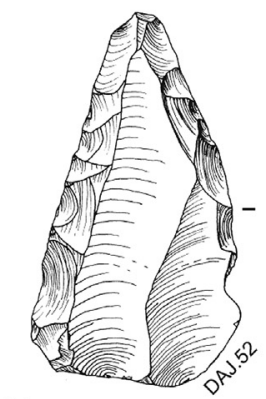

14
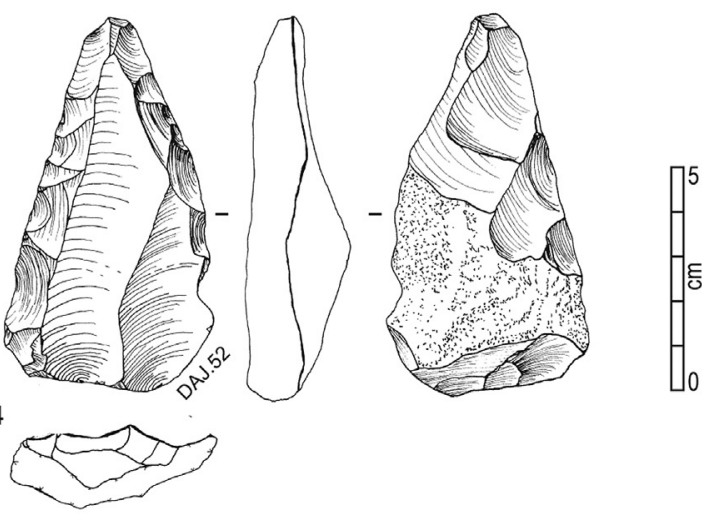

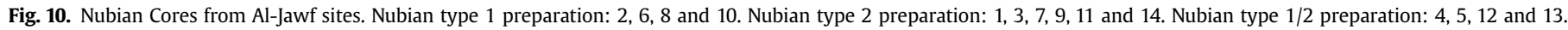

industry of Hummal (levels 5 e to $5 \mathrm{~g}$ ) is placed chronologically between $98 \pm 16$ ka and $128 \pm 18$ ka years based on Thermoluminescence (TL) dates from the lower level $5 g$ (Hauk, 2011). At Mount Carmel, the Qafzeh assemblage, dating to Marine Isotope Stage (MIS) 5 , is marked by the virtual absence of triangular end products and a high amount of centripetal and some bidirectional and unidirectional Levallois core preparation methods (Hovers, 2009). The Split Rock site in central Sinai (Kobusiewicz, 1999) was recently reintroduced in the discussion by Rose and Marks (2014) and was highlighted by Groucutt et al. (2015a) as a possible missing link between Near Eastern Levantine Levallois, northeastern African and Arabian Levallois assemblages. The assemblages (divided into a Lower and an Upper horizon) are composed primarily of debitage; cores and tools are rare. The Lower assemblage, dated by Optically Stimulated Luminescence (OSL) to $\sim 100 \mathrm{ka}$, shows mainly discoid cores with some Levallois cores for flakes and low amounts of 

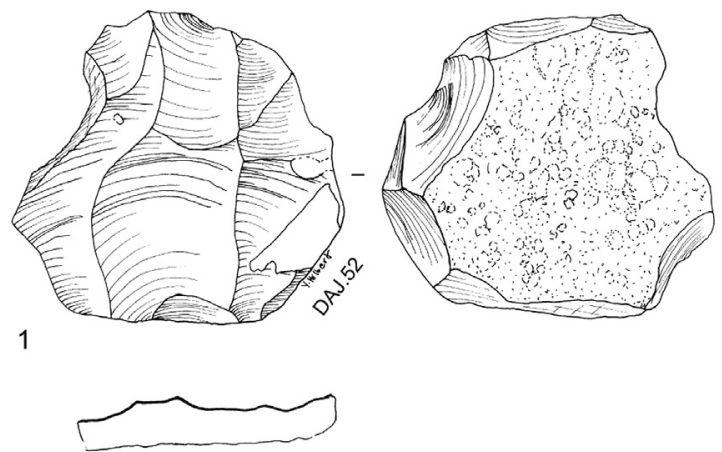

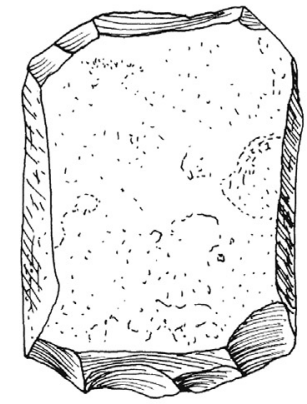

3
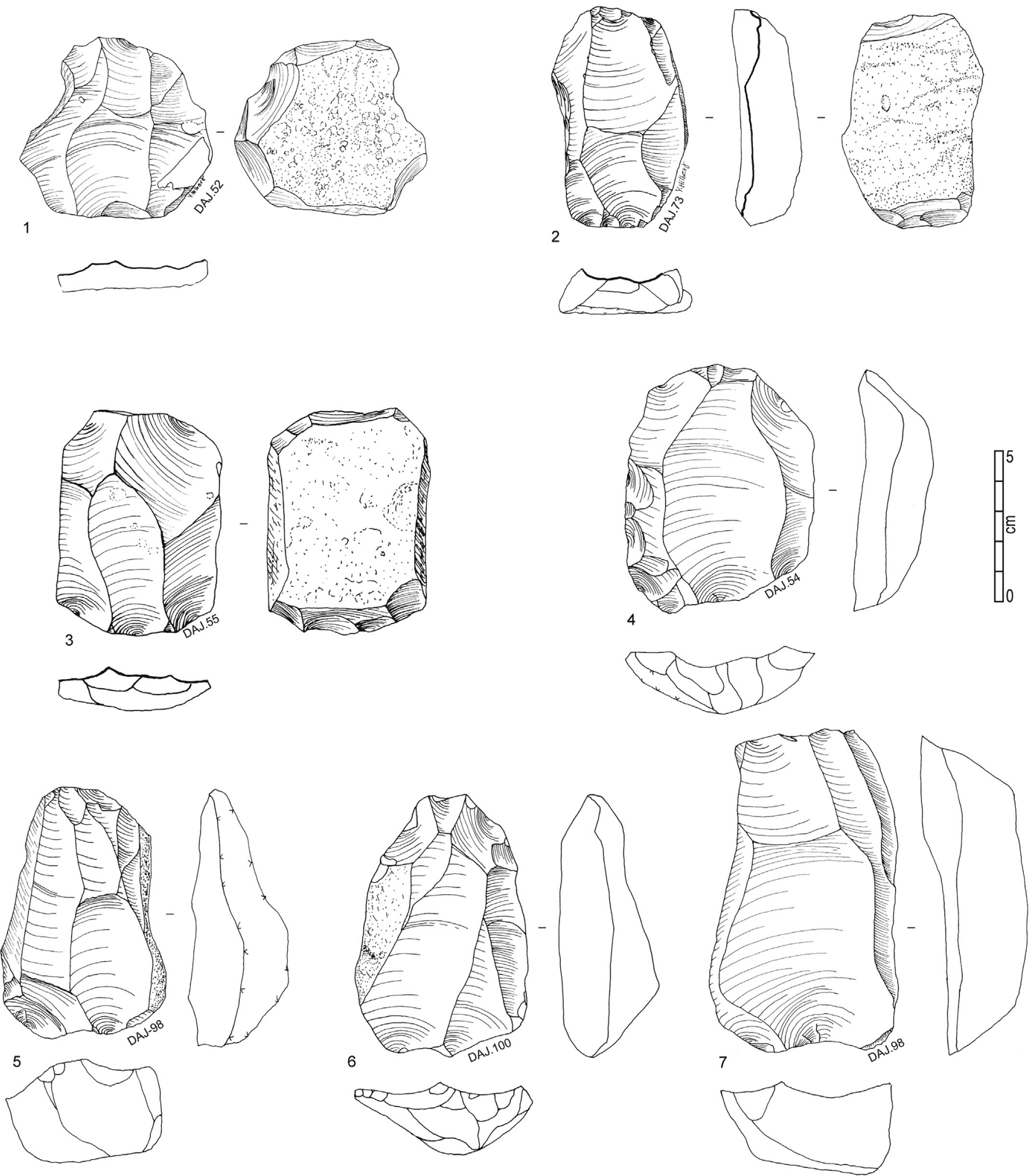

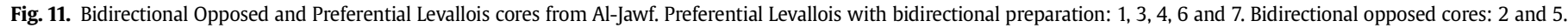

bidirectional-opposed cores. The Upper assemblage, dated to $\sim 75 \mathrm{ka}$, also by OSL (Kobusiewicz et al., 2001), shows preferential Levallois cores, single platform and multi-platform cores. Bidirectional cores are rare.
In Arabia, dated sites with preferential Levallois were excavated in the Jubbah basin in Northern Saudi (Petraglia et al., 2012), the Mundafan area in southern Saudi (Crassard et al., 2013; Groucutt et al., 2015c) and at Jebel Faya NE-1, located in the Emirates 
(Armitage et al., 2011; Bretzke, 2015). Of these sites, JKF-1 in the Jubbah basin, which dates to between $\sim 90-85 \mathrm{ka}$ and $\sim 50 \mathrm{ka}$, is of some interest given the proximity to the Al-Jawf sites. There, mainly single platform unidirectional cores on quartzite and preferential Levallois with centripetal preparation were collected and excavated; a low number of quartz bidirectional and recurrent Levallois cores was also present (Groucutt et al., 2015b). Also located in the Jubbah basin, the site of JSM-1 yielded a small sample of preferential Levallois cores with centripetal and bidirectionalcrossed preparations (Petraglia et al., 2012, fig. 15). In northeastern Africa, Early, Middle and Late Middle Paleolithic (e.g. Van Peer and Vermeersch, 2000, 2007) assemblages present both preferential Levallois with centripetal preparation and Nubian Levallois technologies.

The Nubian Levallois reduction method (and by extension cores) has a relatively concise geographic and temporal range with sites dating roughly to MIS 5 (e.g. Van Peer and Vermeersch, 2007; Rose et al., 2011). Multiple studies were carried out, emphasizing the uniqueness of this specific method of flake production (e.g. Guichard and Guichard, 1965; Van Peer, 1992; Chiotti et al., 2007, 2009; Crassard and Thiébaut, 2011; Crassard and Hilbert, 2013; Usik et al., 2013; Rose and Marks, 2014). Sites were first identified in northern Sudan in the 1960s (Guichard and Guichard, 1965, 1968; Marks, 1968), and have since been discovered throughout the Middle and Lower Nile valley, eastern Sahara oases and the Red Sea hills (Wendorf et al., 1994; van Peer et al., 1996, 2010; Chiotti et al., 2007; Smith et al., 2007; Olszewsky et al., 2010). Nubian Levallois technology and Nubian related artifacts were also found in the Horn of Africa at K'One Crater, Aduma in Ethiopia, Hargeisa in northern Somalia and on the Red Sea coast of Eritrea (Clark, 1954, 1988; Kurashina, 1978; Yellen et al., 2005; Beyin, 2013). Outside of Africa, Nubian Complex occurrences have been found in the Hadramawt region of eastern Yemen (Inizan and Ortlieb, 1987; Crassard, 2009; Crassard and Thiébaut, 2011), Dhofar region of southern Oman (Rose et al., 2011; Usik et al., 2013), southern Rub' al-Khali (Rose and Hilbert, 2014) and the Riyadh province in central Saudi Arabia (Crassard and Hilbert, 2013; Schiettecatte et al., 2013).

In the adjacent desert regions in Jordan and in the Negev, cores exhibiting comparable morphologies, while expressing different chaîne opératoire to those depicted by Nubian cores, are known. Most prominent are the examples from Levels 1 to 3 of Boker Tachtit in the Negev (Marks and Kaufman, 1983; Marks and Volkman, 1983; Volkman, 1983) and assemblages from 'Ain Difla in Jordan (Mustafa and Clark, 2007)'. Ain Difla stands out from other Tabun D-like assemblages, given the extremely high percentage of cores with bidirectional dorsal scar patterns and the presence of elongated pointed blades with faceted striking platforms and bidirectional scars. Both assemblages, however, show a consistent use of cresting technology for the preparation of the surface from which elongated points were produced; an aspect that makes them unlike Nubian Levallois cores, while producing comparable end products. Munday (1976) mentions the presence of Levallois Point cores of the Nubian Type II variety in the Avdat/Aqev Area in the Central Negev. Likewise, Boutié and Rosen (1989) depict a series of Levallois Point cores from the same region that show similar dorsal preparations to that of Nubian cores. Of some interest to the discussion regarding the northernmost distribution of Nubian Complex technology are the recent discoveries at Wadi Sabra, Jordan (Hussain et al., 2015). Similar to the sites found in the Negev region, a handful of Nubian cores ( $n=3$ Nubian $1 / 2)$ are reported. Aside from these findspots, the presence of Nubian technology in the Levant and the desert areas of Jordan, Syria and Lebanon remains anecdotal.

While the results of the lithic analysis from the Al-Jawf Group 3 sites support their attribution to the Afro-Arabian Nubian
Complex, the restricted sample size and lack of chronological control over the surface scatters cannot enable a specific attribution of the finds to either of the previously identified Nubian industries in Dhofar (Classic Dhofar Nubian or Mudayyan) or northeastern Africa (e.g. Early Nubian, Late Nubian, or Taramsan). The analysis of Al-Jawf Group 3 material indicates greater similarities with the NE African and Arabian due to the presence of Nubian Levallois technology, as opposed to the Levantine record. Which is not to say that we see no connection between the Levant and northern Arabia: in fact, assemblages from Al-Jawf attributed to the Group 1 site category, which are characterized by preferential Levallois cores with centripetal preparation, as well as centripetal recurrent Levallois cores, are part of most Middle Paleolithic technological packages found throughout the Near East. On the other hand, preferential centripetal Levallois cores are found widely distributed, somewhat obscuring comparisons when no chronological control over the assemblages is available.

Group 1 and 2 in Al-Jawf bear some resemblances with the Levantine Mousterian and Jubbah paleo-lakeshore sites, while showing very strong tendencies toward bidirectional Levallois architecture and the production of preferential (non triangular) Levallois products. It is not totally excluded that the composition of the Al-Jawf Middle Paleolithic sites corresponds to the 'fusion scenario' for the emergence of the Emiran proposed by Rose and Marks (2014). The lack of crested blades, predominance of elongated triangular end products and Upper Paleolithic tools, as well as the absence of chronological control over the surface assemblages, however, places some constraints on the verification of this hypothesis, based on the data presented here.

Nubian Complex range expansions were likely facilitated by documented wet phases during the Late Pleistocene (Rose et al., 2011; Beyin, 2013; Crassard and Hilbert, 2013; Usik et al., 2013). Increase in precipitation, which would ultimately trigger the formation of lakes, riparian system and the expansion of a savanna type of environment across the Arabian peninsula were linked to the northward migration of the Intertropical Convergent Zone that influenced the range with which the Indian monsoon, the North African summer monsoon and Mediterranean weather systems discharged rainfall over Arabia during the Quaternary (Jennings et al., 2014). Late Pleistocene climate oscillations are a central element when assessing AMH habitat range and expansion. Researchers have speculated that human groups moved out of Africa during climatic favorable conditions (Vaks et al., 2007; Rosenberg et al., 2011). Terrestrial evidence for such pluvial episodes is found throughout Arabia within fluviolacustrine archives (e.g. Rosenberg et al., 2011, 2012; Crassard et al., 2013; Groucutt et al., 2015c), speleothems (e.g. Burns et al., 2001; Fleitmann et al., 2011), and deep-sea cores from the Arabian Sea (e.g. Schultz et al., 1998). In sum, the palaeoenvironmental data indicates that widespread pluvial phases occurred during MIS 5e (128-120 ka), MIS 5c (110-100 ka) and MIS 5a (90-74 ka), which were reflected by the extension of savannah conditions throughout parts of the Arabian Peninsula and North Africa (e.g. Parker and Rose, 2008; Parker, 2009; Preusser, 2009). It is likely that Nubian Levallois technology was introduced in Arabia before MIS 5c, given that dates from Aybut al-Auwal in southern Oman (Rose et al., 2011). Further research and additional dated sites with Nubian Levallois technology in Arabia are needed to further develop any theories on the dispersal of this Techno-Complex across this area. Prior to this study, northern Saudi Arabia had undergone only cursory survey, and in particular the isolated Al-Jawf region (Adams et al., 1977; Parr et al., 1978). The sites and data presented here add to the growing record of Arabian Paleolithic. 


\section{Conclusion}

We have presented the first technological analysis of Middle Paleolithic assemblages from surface sites in the Al-Jawf province of northern Saudi Arabia. The technological analysis of these assemblages has revealed four different groups of sites. We have attempted to draw parallels between the Al-Jawf sites and those in a wider area, including North Africa, the Levant and Arabia. The comparison with the Near East and North Arabia assemblages revealed some similarities in the form of the use of Levallois preferential technology for the production of predetermined flakes. Nonetheless, the Al-Jawf assemblages are heavily reliant on the use of bidirectional and bidirectional-crossed preparations of the Levallois surface.

Further research and chronological control over the Al-Jawf sites would be most useful for regional comparisons. In the absence of stratified Nubian Complex sites in Al-Jawf, any specific chronological attribution, beyond a broad MIS 5 to MIS 3 spectrum, must remain hypothetical. Combined with the evidence from Al-Kharj 22 in central Saudi Arabia, the Al-Jawf discoveries testify to the widespread distribution of Nubian Levallois technology in Arabia. It becomes increasingly evident that Nubian technology, and ultimately the greater distribution of the Nubian Complex across the Peninsula, is not restricted to southern Arabia. Lithics alone, however, cannot provide verification of the earlier posited routes of expansions, represented in the literature by linear arrows on maps traversing myriad landscapes seemingly without context. Equally, while the occurrence of Nubian cores across the Arabian Peninsula suggest some degree of cultural permeability between northeast Africa and Arabia, the complex mechanics behind these processes remain to be determined, and dated.

\section{Acknowledgments}

We are grateful to the Saudi Commission for Tourism and Antiquities for their support and permission to conduct survey activities in the province of Al-Jawf. The SCTA, the French and Italian Ministries of Foreign Affairs, CNRS UMR-8167 Orient \& Méditerranée, the University L'Orientale of Naples provided financial support for the archaeological investigations in Dumat alJandal area (to GC \& RL), as well as CNRS UMR-5133 Archéorient (to RC) and Fondation Fyssen ('Subvention de Recherche 2013' grant to $\mathrm{RC}$ ). YHH is most grateful to the Fondation Fyssen for financing his postdoctoral research at the Archéorient laboratory in Lyon. The authors also thank Anthony E. Marks for valuable comments and discussion on an earlier draft of this manuscript. We also extend our gratitude to the organizers of the UISPP Session 21c "Movements in and Out for Africa" as well as to two anonymous reviewers for their observations and suggestions, which have greatly improved the quality of this manuscript.

\section{Appendix A. Supplementary data}

Supplementary data related to this article can be found at http:// dx.doi.org/10.1016/j.quaint.2015.11.047.

\section{References}

Adams, R.McC., Parr, P.J., Ibrahim, M., al-Mughannum, A.S., 1977. Saudi Arabian archaeological reconnaissance 1976; the preliminary report on the first phase of the comprehensive archaeological survey program. Atlal. The Journal of Saudi Arabian Archaeology Riyadk 1, 21-40.

Armitage, S.J., Jasim, S., Marks, A., Parker, A.G., Usik, V.I., Uerpmann, H., 2011. The Southern route "Out of Africa": evidence for an early expansion of modern humans into Arabia. Science 331, 453-456.
Bar-Yosef, O., 1980. Prehistory of the Levant. Annual Review of Anthropology 9, $101-133$.

Bar-Yosef, O., 1987. Pleistocene connections between Africa and Southwest Asia: an archaeological perspective. African Archaeological Review 5, 29-38.

Beyin, A., 2013. A surface Middle Stone Age assemblage from the Red Sea coast of Eritrea: implications for Upper Pleistocene human dispersals out of Africa. Quaternary International 300, 195-212.

Boëda, E., 1994. Le concept Levallois: variabilité des méthodes. Monographie du CRA, 9. CNRS, Paris.

Boëda, E., 1995. Levallois: a volumetric construction, methods, a technique. In: Dibble, H. Bar-Yosef, O. (Eds.), The Definition and Interpretation of Levallois Technology, Monographs in World Archaeology, vol. 23. Prehistory Press, Madison, pp. 41-68.

Bordes, F., 1980. Le débitage Levallois et ses variantes. Bulletin de la Société Préhistorique Française 77, 45-49.

Boutié, P., Rosen, S.A., 1989. Des gisements moustériens dans le Néguev central. Résultats préliminaires de prospections récentes. In: Bar-Yosef, $\mathrm{O}$. Vandermeersch, B. (Eds.), Investigations in South Levantine Prehistory/Préhistoire du Sud-Levant, British Archaeological Reports 497. Oxford, pp. 147-166.

Bretzke, K., 2015. Paleolithic assemblages from the Central Region of the Emirate of Sharjah (UAE) and implications for human settlement dynamics in Southern Arabia. In: Conard, N.J., Delagnes, A. (Eds.), Settlement Dynamics of the Middle Paleolithic and Middle Stone Age, vol. 4. Tübingen Publications in Prehistory, Kerns Verlag, Tübingen, pp. 105-125.

Burns, S., Fleitmann, D., Matter, A., Neff, U., Mangini, A., 2001. Speleothem evidence from Oman for continental pluvial events during interglacial periods. Geology 29, 623-626.

Cameron, D.W., Grove, C.P., 2004. Bones, Stones, and Molecules: "out of Africa" and Human Origins. Elsevier Academic Press, San Diego.

Chiotti, L., Olszewski, D.I., Dibble, H.L., McPherron, S.R., Schurmans, U., et al., 2007. Paleolithic Abydos: reconstructing individual behaviors across the high desert landscape. In: Hawass, Z., Richards, J. (Eds.), The Archaeology and Art of Ancient Egypt: Essays in Honor of David B O'Connor. Supreme Council of Antiquities Press Cairo, Cairo, pp. 169-183.

Chiotti, L, Dibble, H.L. Olszewski, D.I., McPherron, S.R., Schurmans, U., 2009. Middle Palaeolithic lithic technology from the western high desert of Egypt. Journal of Field Archaeology 34, 307-318.

Clark, J.D., 1954. The Prehistoric Cultures of the Horn of Africa. Cambridge University Press, Cambridge.

Clark, J.D., 1988. Middle Stone Age of East Africa and the beginnings of regional identity. Journal of World Prehistory 2, 235-305.

Crassard, R. 2009. Middle Paleolithic in Arabia: the view from the Hadramawt region, Yemen. In: Petraglia, M.D., Rose, J.I. (Eds.), The Evolution of Human Populations in Arabia. Paleoenvironments, Prehistory and Genetics. Springer Academic Publishers, Dordrecht, pp. 151-168.

Crassard, R., Thiébaut, C., 2011. Levallois points production from eastern Yemen and some comparisons with assemblages from East-Africa, Europe and the Levant. In: Le Tensorer, J.M., Jagher, R., Otte, M. (Eds.), The Lower and Middle Palaeolithic in the Middle East and Neighboring Regions. ERAUL, Liège, pp. 131-142.

Crassard, R., Hilbert, Y.H., 2013. A Nubian Complex site from central Arabia: implications for Levallois taxonomy and human dispersals during the Upper Pleistocene. PLoS One 8, e69221.

Crassard, R., Petraglia, M.D., Drake, N.A., Breeze, P., Gratuze, B., Alsharekh, A., Arbach, M., Groucutt, H.S., Khalidi, L., Michelsen, N., Robin, C.J., Schiettecatte, J., 2013. Middle Palaeolithic and Neolithic occupations around Mundafan Palaeolake, Saudi Arabia: implications for climate change and human dispersals. PLoS One 8, e69665.

Delagnes, A., Tribolo, C., Bertran, P., Brenet, M., Crassard, R., Jaubert, J., Khalidi, L., Mercier, N., Nomade, S., Peigné, S., Sitzia, L., Tournepiche, J., Al-halibi, M., Almosabi, A., Macchiarelli, R., 2012. Inland human settlement in southern Arabia 55,000 years ago. New evidence from the Wadi Surdud Middle Paleolithic site complex, western Yemen. Journal of Human Evolution 63, 452-474.

Delagnes, A., Crassard, R., Bertran, P., Sitzia, L., 2013. Cultural and human dynamics in southern Arabia at the end of the Middle Palaeolithic. Quaternary International 300, 234-243.

Derricourt, R., 2005. Getting "Out of Africa": sea crossings, land crossings and culture in the Hominin migrations. Journal of World Prehistory 19, 119-132.

Fleitmann, D., Burns, S.J., Pekala, M., Mangini, A., Al-Subbary, A., Al-Aowah, M., Kramers, J., Matter, A., 2011. Holocene and pleistocene pluvial periods in Yemen, Southern Arabia. Quaternary Science Review 30, 783-787.

Ghirotto, S., Penso-Dolfin, L., Barbujani, G., 2011. Genomic evidence for an African expansion of anatomically modern humans by a southern route. Human Biology 83, 477-489.

Groucutt, H.S., Scerri, E.M.L., Lewis, L., Clark-Balzan, L., Blinkhorn, J., Jennings, R.P., Parton, A., Petraglia, M.D., 2015a. Stone tool assemblages and models for the dispersal of Homo sapiens out of Africa. Quaternary International 382, 8-30.

Groucutt, H.S., Shipton, C., Alsharekh, A., Jennings, R., Scerri, E.M.L., Petraglia, M.D., 2015b. Late Pleistocene lakeshore settlement in northern Arabia: Middle Palaeolithic technology from Jebel Katefeh, Jubbah. Quaternary International 382, 215-236.

Groucutt, H.S., White, T., Clark-Balzan, L., Parton, A., Crassard, R., Shipton, C., Jennings, R.P., Parker, A.G., Breeze, P.S., Scerri, E.M.L., Alsharekh, A. Petraglia, M.D., 2015c. Human occupation of the Arabian Empty Quarter during MIS 5: evidence from Mundafan Al-Buhayrah, Saudi Arabia. Quaternary Science Reviews 119, 116-135. 
Guichard, J., Guichard, G., 1965. The Early and Middle Palaeolithic of Nubia: a preliminary report. In: Wendorf, F. (Ed.), Contributions to the Prehistory of Nubia. Southern Methodist University Press, Dallas, pp. 57-116.

Guichard, J., Guichard, G., 1968. Contribution to the study of the Early and Middle Palaeolithic of Nubia. In: Wendorf, F. (Ed.), The Prehistory of Nubia. Fort Burgwin Research Center and Southern Methodist University Press, Dallas, pp. $148-193$.

Hauck, T., 2011. The Mousterian sequence of Hummal and its tentative placement in the Levantine Middle Palaeolithic. In: Le Tensorer, J-M., Jagher, R., Otte, M. (Eds.), The Lower and Middle Palaeolithic in the Middle East and Neighbouring Regions. ERAUL 126, Liège, pp. 309-323.

Hovers, E., 2009. The Lithic Assemblages of Qafzeh Cave. Oxford University Press, Oxford.

Hussain, S.T., Richter, J., Schyle, D., Kindermann, K., Wolter, T., Hauck, T.C., 2015. The veiled Mousterian: traces of Middle Palaeolithic presence in the Wadi Sabra. In: Schyle, D., Richter, J. (Eds.), Pleistocene Archaeology of the Petra Area in Jordan, Kölner Studien zur Prähistorischen Archäologie 5. Marie Leidorf, Rahden/Westf, pp. $55-85$.

Inizan, M.L., Ortlieb, L., 1987. Préhistoire dans la région de Shabwa au Yémen du Sud (R.D.P. Yémen). Paléorient 13, 5-22.

Jennings, R., Singarayer, S., Stone, E., Krebs-Kanzo, U., Khon, V., Nisancioglu, K.H., Parker, A.G., Parton, A., Groucutt, H.S., White, T.S., Drake, N.A., Petraglia, M.D., 2014. The greening of Arabia: multiple opportunities for human occupation of the Arabian Peninsula during the Late Pleistocene inferred from an ensemble of climate model simulations. Quaternary International 382, 181-199.

Klein, R., 2009. The Human Career, Human Biological and Cultural Evolution, third ed. The University of Chicago Press, Chicago and London.

Kobusiewicz, M., 1999. Excavations at Sinai-20, the split rock site, Zarnoq locality. In: Eddy, F.W., Wendorf, F. (Eds.), An Archaeological Investigation of the Central Sinai, Egypt. American Research Center, Cairo and Colorado University Press, Niwot, pp. 193-207.

Kobusiewicz, M., Schild, R., Bluszcz, A., Wendorf, F., 2001. Reassessing chronostratigraphic position of the split rock site, Sinai. In: Gehlen, B., Heinen, M. Tillmann, A. (Eds.), Zeit-Raüme, Gedenkschirft für Wolfgang Taute, Band 1, Bonn, pp. 227-236.

Kurashina, H., 1978. An Examination of Prehistoric Lithic Technology in East-Central Ethiopia (Ph.D. dissertation). University of California, Berkeley.

Lahr, M.M., Foley, R., 1994. Multiple dispersals and modern human origins. Evolutionary Anthropology 3, 48-60.

Macaulay, V., Hill, C., Achilli, A., Rengo, C., Clarke, D., Meehan, W., Blackburn, J., Semino, O., Scozzari, R., Cruciani, F., Taha, A., Shaari, N.K., Raja, J.M., Ismail, P., Zainuddin, Z., Goodwin, W., Bulbeck, D., Bandelt, H.-J., Oppenheimer, S. Torroni, A., Richards, M., 2005. Single, rapid coastal settlement of Asia revealed by analysis of complete mitochondrial genomes. Science 308, 1034-1036.

Marks, A.E., 1968. The mousterian industries of Nubia. In: Wendorf, F. (Ed.), The Prehistory of Nubia, vol. 1. Southern Methodist University Press, Dallas, pp. 194-314.

Marks, A.E., 1992. Upper Pleistocene archaeology and the origins of modern Man: a view from the Levant and adjacent areas. In: Akazawa, T., Aoki, K., Kimura, T. (Eds.), The Evolution and Dispersal of Modern Humans in Asia. Hokusen-sha Press, Tokyo, pp. 229-253.

Marks, A.E., 2009. The Paleolithic of Arabia in an intra-regional context. In: Petraglia, M.D., Rose, J.I. (Eds.), Evolution of Human Populations in Arabia: Paleoenvironments, Prehistory and Genetics. Springer Academic Publishers, Dordrecht, pp. 293-309.

Marks, A.E., Kaufman, D., 1983. Boker tachtit: the artifacts. In: Marks, A.E. (Ed.), Prehistory and Paleoenvironments in the Central Negev, Israel, Volume III, the Avdat/Aqev Area, Part 3. Department of Anthropology, Southern Methodist University, Dallas, pp. 69-126.

Marks, A.E., Rose, J.I., 2014. A century of research into the origins of the Upper Paleolithic in the Levant. In: Otte, M. (Ed.), Neandertal/Cro-Magnon: La Rencontre. Éditions Errance, Arles, pp. 221-266.

Marks, A.E., Volkman, P., 1983. Changing core reduction strategies: a technological shift from the Middle to the Upper Palaeolithic. In: Trinkaus, E. (Ed.), The Mousterian Legacy: Human Biocultural Change in the Upper Pleistocene, British Archaeological Reports International Series S164. Archaeopress, Oxford, pp. 35-51.

McKee, E.D., 1979. Sedimentary structures in dunes. In: McKee, E.D. (Ed.), A Study of Global Sand Seas: Geological Survey Professional Paper, United States: Geological Survey, pp. 83-137.

Meignen, L., 1995. Levallois lithic production systems in the Middle Palaeolithic of the Near East: the case of the unidirectional method. In: Dibble, H.L., Bar-Yosef, O. (Eds.), The Definition and Interpretation of Levallois Technology, Monographs in World Archaeology, vol. 23. Prehistory Press, Madison, pp. 361-380.

Meissner, C.R., Dini, S.M., Farasani, A.M., Riddler, G.P., van Eck, M., Aspinall, N.C., 1989. Preliminary Geologic Map of the Al Jawf Quadrangle; Sheet 29D, Kingdom of Saudi Arabia Directorate General of Mineral Resources Open. File Report USGS-OF-09-1.

Monigal, K., 2002. The Levantine Leptolithic: Blade Technology from the Lower Palaeolithic to the Dawn of the Upper Palaeolithic (Ph.D. dssertation). Southern Methodist University.

Munday, F., 1976. Intersite variability in the mousterian occupation of the Advat/ Aqev area. In: Marks, A.E. (Ed.), Prehistory and Paleoenvironment in the Central Negev, Israel. SMU Press, Dallas, pp. 113-140.
Mustafa, M., Clark, G.A., 2007. The 'Ain Difla rockshelter (Jordan) and the evolution of Mousterian technology: implications for Modern Human origins. Eurasian Prehistory 5 (1), 47-83.

Olszewski, D.I., Dibble, H.L., McPherron, S.P., Schurmans, U., Chiotti, L., Smith, J., 2010. Nubian Complex strategies in the Egyptian high desert. Journal of Human Evolution 59, 188-201.

Parker, A.G., 2009. Pleistocene climate change in Arabia: developing a framework for Hominin dispersal over the last 350 ka. In: Petraglia, M.D., Rose, J.I. (Eds.) The Evolution of Human Populations in Arabia: Paleoenvironments, Prehistory and Genetics. Springer Academic Publishers, Dordrecht, pp. 151-168.

Parker, A.G., Rose, J.I., 2008. Climate change and human origins in southern Arabia. Proceedings of the Seminar for Arabian Studies 38, 25-42.

Parr, P.J., Zarins, J., Ibrahim, M., Waechter, J., Garrard, A., Clarke, C., Bidmead, M., alBadr, H., 1978. Preliminary report on the second phase of the Northern province survey 1397/1977. Atlal. The Journal of Saudi Arabian Archaeology Riyadk 2, $29-50$.

Petraglia, M.D., Rose, J., 2009. The Evolution of Human Populations in Arabia. Paleoenvironments, Prehistory and Genetics. Springer, London.

Petraglia, M.D., 2011. Trailblazers across Arabia. Nature 470, 50-51.

Petraglia, M.D., Alsharekh, A., Breeze, P., Clarkson, C., Crassard, R., Drake, N.A. Groucutt, H.S., Jennings, R., Parker, A.G., Parton, A., Roberts, R.G., Shipton, C. Matheson, C., al-Omari, A., Veall, M.A., 2012. Hominin dispersal into the Nefud Desert and Middle Palaeolithic settlement along the Jubbah Palaeolake, Northern Arabia. PLoS One 7, e49840.

Preusser, F., 2009. Chronology of the impact of Quaternary climate change on continental environments in the Arabian Peninsula. Comptes Rendues Geoscience 34, 621-632.

Quintana-Murci, L., Semino, O., Bandelt, H.J., 1999. Genetic evidence of an early exit of Homo sapiens sapiens from Africa through eastern Africa. Nature Genetic 23 437-441.

Richter, J., Hauck, T., Vogelsang, R., Widlok, T., Le Tensorer, J.M., Schmid, P., 2012. "Contextual areas" of early Homo sapiens and their significance for human dispersal from Africa into Eurasia between $200 \mathrm{ka}$ and $70 \mathrm{ka}$. Quaternary International 274, 5-24.

Rose, J.I., Hilbert, Y.H., 2014. New Prehistoric Sites in the Southern Rub' al-Khali desert, Oman. Antiquity 88 (381). Project Gallery.

Rose, J.I., Marks, A.E., 2014. "Out of Arabia” and the Middle-Upper Palaeolithic transition in the southern Levant. Quartär 61, 49-85.

Rose, J.I., Usik, V.I., Marks, A.E., Hilbert, Y.H., Galletti, C.S., Parton, A., Geiling, J.M., Cerný, V., Morley, M.W., Roberts, R.G., 2011. The Nubian Complex of Dhofar, Oman: an African Middle Stone Age Industry in Southern Arabia. PLoS One 6, e28239.

Rosenberg, T., Preusser, F., Fleitmann, D., Schwalb, A., Penkman, K., Schmid, T.W., AlShanti, M.A., Kadi, K., Matter, A., 2011. Human periods in southern Arabia: windows of opportunity for modern human dispersal. Geology 39, 1115-1118.

Rosenberg, T.M., Preusser, F., Blechschmidt, I., Fleitmann, D., Jagher, R., Matter, A. 2012. Late Pleistocene palaeolake in the interior of Oman: a potential key area for the dispersal of anatomically modern humans out-of-Africa? Journal of Quaternary Sciences 27, 13-16.

Scerri, E.M.L., Groucutt, H.S., Jennings, R.P., Petraglia, M.D., 2014. Unexpected technological heterogeneity in northern Arabia indicates complex Late Pleistocene demography at the gateway to Asia. Journal of Human Evolution 75 $125-142$

Schiettecatte, J., al-Ghazzi, A., Charloux, G., Crassard, R., Hilbert, Y.H., Monchot, H., Mouton, M., Siméon, P., 2013. Al-Kharj oasis through time: first results of archaeological fieldwork in the province of Riyadh (Saudi Arabia). Proceedings of the Seminar for Arabian Studies 43, 285-308.

Schulz, H., van Rad, U., Erlenkeuser, H., 1998. Correlation between Arabian Sea and Greenland climate oscillations of the past 110,000 years. Nature $393,54-57$.

Shea, J.J., 2003. The Middle Paleolithic of the east Mediterranean Levant. Journal of World Prehistory 17, 313-394.

Smith, J.R., Hawkins, A.L., Asmerom, Y., Polyak, V., Giegengack, R., 2007. New age constraints on the Middle Stone Age occupations of Kharga Oasis, Western Desert, Egypt. Journal of Human Evolution 52, 690-701.

Usik, V.I., Rose, J.I. Hilbert, Y.H., Van Peer, P., Marks, A.E., 2013. Nubian Complex reduction strategies in Dhofar, southern Oman. Quaternary International 300, 244-266.

Van Peer, P., 1992. The Levallois Reduction Strategy. In: Monographs in World Archaeology, vol. 13. Prehistory Press, Madison.

Van Peer, P., Vermeersch, P.M., 2000. The Nubian Complex and the dispersal of modern humans in North Africa. In: Krzyzaniak, L., Kroeper, K., Kobusiewicz, M. (Eds.), Recent Research into the Stone Age of Northeastern Africa. Poznan Archaeological Museum, Poznan, pp. 47-60.

Van Peer, P., Vermeersch, P.M., 2007. The place of northeast Africa in the early history of modern humans: new data and interpretations on the Middle Stone Age. In: Mellars, P., Boyle, K., Bar-Yosef, O., Stringer, C. (Eds.), Rethinking the Human Revolution. McDonald Institute for Archaeological Research, Cambridge, pp. 187-198.

Van Peer, P., Vermeersch, P.M., Moeyersons, J., Van Neer, W., 1996. Paleolithic sequence of Sodmein Cave, Red Sea Mountains, Egypt. In: Pwiti, G., Soper, R (Eds.), Aspects of African Archaeology. University of Zimbabwe Publications, Harare, pp. 149-156.

Van Peer, P., Vermeersch, P.M., Paulissen, E., 2010. Chert Quarrying, Lithic Technology and a Modern Human Burial at the Palaeolithic Site of Taramsa 1, Upper Egypt. Leuven University Press, Leuven. 
Vaks, A., Bar-Matthews, M., Ayalon, A., Matthews, A., Halicz, L., Frumkin, A., 2007. Desert speleothems reveal climatic window for African exodus of early modern humans. Geology 35 (9), 831-834.

Volkman, P., 1983. Boker Tachtit: core reconstructions. In: Marks, A.E. (Ed.), Prehistory and Paleoenvironments in the Central Negev, Israel, vol. III, the Avdat/Aqev Area, Part 3. Department of Anthropology, Southern Methodist University, Dallas, pp. 127-190.

Wallace, C.A., Dini, S.M., Al-Farasani, A.A., 1997. Explanatory Notes to the Geological Map of the Al Jawf Quadrangle, Kingdom of Saudi Arabia. Geoscience Map GM128C, Scale 1:250,000, Sheet 29D. Deputy Ministry for Mineral Resources, Ministry of Petroleum and Mineral Resources, Kingdom of Saudi Arabia.
Wendorf, F., Schild, R., Close, A.E., Schwarcz, H.P., Miller, G.H., Grün, R., Bluszcz, A., Stokes, S., Morawska, L., Huxtable, J., Lundberg, J., Hill, C.L., McKinney, C., 1994. A chronology for the middle and late Pleistocene wet episodes in the eastern Sahara. In: Bar-Yosef, O., Kra, R.S. (Eds.), Late Quaternary Chronology and Paleoclimates of the Eastern Mediterranean. Department of Geosciences, University of Arizona, Tucson, pp. 147-168.

Yellen, J., Brooks, A., Helgren, D., Tappen, M., Ambrose, S., Bonnefille, R., Feathers, J., Goodfriend, G., Ludwig, K., Renne, P., Stewart, K., 2005. The archaeology of Aduma Middle Stone Age sites in the Awash Valley, Ethiopia. Paleoanthropology 10, 25-100. 